This article can be cited as: Rabat, Á., Cano, M., Tomás, R., Tamayo, A.E., Alejano, L.R. Evaluation of Strength and Deformability of Soft Sedimentary Rocks in Dry and Saturated Conditions Through Needle Penetration and Point Load Tests: A Comparative Study. Rock Mech Rock Eng (2020). https://doi.org/10.1007/s00603-020-02067-6

\title{
Evaluation of strength and deformability of soft sedimentary rocks in dry and saturated conditions through needle penetration and point load tests: a comparative study
}

\author{
Á. Rabat ${ }^{\mathrm{a}^{*}}$, M. Cano ${ }^{\mathrm{a}}$, R. Tomás ${ }^{\mathrm{a}}$, Á.E. Tamayo ${ }^{\mathrm{a}}$, L.R. Alejano ${ }^{\mathrm{b}}$ \\ a Department of Civil Engineering, University of Alicante. Carr. San Vicente del Raspeig, 03690, San Vicente del Raspeig, Alicante, \\ Spain \\ b Department of Natural Resources and Environmental Engineering, University of Vigo. Campus Universitario Lagoas-Marcosende, \\ s/n, 36310, Vigo, Spain \\ *Corresponding author: Álvaro Rabat (alvaro.rabat@ua.es). Tel: +34 654728646
}

\begin{abstract}
The preparation of standardized soft rock specimens to perform unconfined compressive strength (UCS) tests is typically difficult, expensive and time-consuming. Needle Penetration Test (NPT) was originally developed in Japan as an alternative for the indirect estimation of UCS of soft rocks. The needle penetrometer is a simple, portable and non-destructive testing device that measures applied load and penetration depth for the rock to calculate the needle penetration index (NPI). A complimentary, portable and widely used destructive test is the point load test (PLT), which measures regular and irregular specimens by the application of a concentrated load using two coaxial conical platens that yield the point load strength index $\left(\mathrm{I}_{\mathrm{s}(50)}\right)$. We investigated and compared the NPT and PLT in terms of measuring changes induced by water saturation and obtaining UCS and the static Young's modulus (Est) for dry and saturated soft sedimentary rocks. The results point to significant correlation functions from which to infer UCS and $E_{s t}$ in terms of NPI and $\mathrm{I}_{\mathrm{s}_{(50)}}$ in dry and saturated soft rocks. Furthermore, both NPT and PLT are suitable tests for evaluating changes in strength and deformability induced by water saturation. We also found a good correlation between the $\mathrm{NPI}$ and $\mathrm{I}_{s(50)}$.
\end{abstract}

\section{Keywords}

needle penetration test, dry and saturated conditions, soft sedimentary rocks, strength and deformability, point load test

\section{List of abbreviation and symbols}

FLD: field

LAB: laboratory

NPI: needle penetration index

NPT: needle penetration test

PLT: point load test

UCS: unconfined compressive strength

$E_{s t}$ static Young's modulus

$I_{s(50)}$ : point load strength index

k: Ratio between UCS and $I_{s(50)}$

F: applied load in the NPT

D: penetration depth in the NPT

$\rho_{d}$ : dry density

$\rho_{\text {sat }}$ : saturated density

$p_{0}$ : open porosity

p: total porosity

$\mathrm{W}_{\mathrm{a}}$ : water absorption

$\chi$ : mean value

$\sigma:$ standard deviation

$\mathrm{R}$ : coefficient of correlation

$\mathrm{R}^{2}$ : coefficient of determination 


\section{Acknowledgements}

This research was supported by the Vice-rector of Research and Knowledge Transfer of the University of Alicante through predoctoral grant FPUUA53-2018 and projects UAUSTI18-21 and UAEEBB2018-09. The authors thank the Earth Sciences Department of the University of Alicante for allowing them to perform the thin-section analyses in their laboratories. Ailish M. J. Maher is gratefully acknowledged for the language editing of a version of this manuscript.

\section{INTRODUCTION}

Unconfined compressive strength (UCS) is an essential geomechanical property for rock mass characterization, description and classification, widely used in mining, civil engineering, geotechnical and infrastructure projects. While the test procedure itself is relatively simple, UCS determination is expensive and time-consuming because of the need to use heavy test equipment and well-prepared standard specimens. Furthermore, for certain rock types, e.g., argillaceous and very soft rock, it is especially complicated to prepare specimens of the size and shape necessary to carry out strength and deformability tests (Li et al., 2016).

For those reasons, UCS has traditionally been indirectly assessed using alternative methods like the point load test (PLT) and Schmidt hammer test. The PLT can be conducted using irregularly shaped specimens, thereby eliminating the need to use heavy laboratory equipment, but the drawback is that it is difficult to obtain a unique accurate value for the $\mathrm{k}$ factor correlating the point load strength index $\left(I_{s(50)}\right)$ and UCS (i.e. $\left.k=U C S / I_{s(50)}\right)$, given the strong effects of weathering degree and rock type (Ulusay and Erguler, 2012). As for the Schmidt hammer test, this can be used to estimate the UCS in field geotechnical surveys but has two drawbacks, namely, that it is not suitable for rocks with UCS values lower than $10 \mathrm{MPa}$ (Ulusay and Erguler, 2012) and it cannot be applied in a non-destructive manner in soft rocks, given that high-energy impacts can cause microcracking, grain crushing and pore collapse in friable, porous or weathered rock specimens (Aydin, 2009). Those tests, therefore, are not suitable for in situ non-destructive tests to determine mechanical properties in natural soft rock structures, monuments or heritage or ancient constructions built with natural stone (Ulusay et al., 2014).

With the aim of overcoming the above-mentioned limitations, a needle penetrometer was developed by the Rock Mechanics Committee of the Japan Society of Civil Engineers (JSCE-RMC) as a portable and non-destructive testing device for soft rock specimens. NPT is similar to the Cone Indention Test developed at the National Coal Board of England to determine both the Indentation Hardness Index (IHI) and UCS of rock (Szwedzicki, 1998; Tiryaki and Bolukbasi, 2007). In this sense, Kahraman and Gunaydin (2008) obtained that IHI can be used for predicting the sawability of carbonate rocks and Kahraman et al. (2012) suggested correlation functions to indirectly predict the UCS and the Brazilian Tensile Strength (BTS) from the IHI. In this connection, NPT could be also used for the determination of the specific energy of cutting or for the indirect determination of strength parameters of soft rocks, such as the UCS. This approach, especially suitable for testing specimens with UCS values lower than $20 \mathrm{MPa}$, has three major advantages: NPT can be used in the field or laboratory, the specimens do not require any special preparation, and it is non-destructive (Ulusay et al., 2014). The NPI has been mostly used to calculate the UCS of sedimentary soft rocks (like marls, shales, sandstones and argillaceous rocks) in a dry state in laboratory tests or with their natural water content in field surveys. However, very little research has focused on NPI estimates for fully water saturated specimens or on the NPI relationships with both the static Young's modulus $\left(E_{s t}\right)$ and the $I_{s(50)}$. 
Our study tries to close all those gaps. Specifically, our main objectives were: (a) to evaluate the changes induced by water saturation of siltstone and gypsiferous rock using the NPT and PLT; (b) to verify the suitability of the NPT and PLT to indirectly obtain the UCS and $E_{\text {st }}$ of siltstone and gypsiferous rock in dry and saturated water conditions; and (c) to evaluate significant relationships between the $I_{s(50)}$ and the NPI.

\section{PREVIOUS STUDIES}

A seminal study on the relationship between the NPI and UCS was conducted by Ulusay and Erguler (2012), who developed a database consisting of more than 700 NPI-UCS data pairs for different rock types (marl, siltstone, mudstone, sandstone, greywacke, tuff and shale), obtained from both previous publications and their own tests. Those authors suggested the following correlation function:

$$
\mathrm{UCS}=0.4 \cdot \mathrm{NPI}^{0,929}(\mathrm{Eq} \cdot 1)
$$

where UCS is measured in MPa and the NPI in N/mm.

Although the correlation proposed by those authors is a power function, Aydan (2012) subsequently found the following linear relationship between both parameters for numerous rock types (tuff, sandstone, pumice, limestone, lignite, mudstone, siltstone, marl and loam):

$$
\mathrm{UCS}=0.2 \cdot \mathrm{NPI} \quad(\mathrm{Eq} .2)
$$

where UCS is measured in MPa and the NPI in N/mm.

Aydan (2012) suggested that correlation would be improved if the fitting function was obtained individually for each rock type, further indicating that the conversion factor usually takes a value between 0.06 and 0.70 .

Aydan and Ulusay (2013) subsequently obtained the following linear correlation for Turkish tuff:

$$
\mathrm{UCS}=0.3 \cdot \mathrm{NPI}(\text { Eq. } 3)
$$

where UCS is measured in MPa and the NPI in N/mm.

Others authors have found significant relationships between the NPI and UCS for several natural soft rock types (Okada et al., 1985; Yamaguchi et al., 1997; Takahashi et al., 1998; Naoto et al., 2004; Uchida et al., 2004; Kahraman et al., 2017). Furthermore, the NPT is now widely implemented in Japan to check quality and estimate UCS for soilcrete columns using the highpressure chemical churning pile (jet grouting) method originally devised by Ichise et al. (1974).

Most of the correlations proposed in the literature, compiled in Table 1, are linear or power functions. Regarding the relationship between $E_{s t}$ and the NPI, Aydan (2012) found a linear correlation between both parameters for tuffs, lignites, sandstones and limestones, suggesting that the conversion factor usually varies between 0.015 and 0.120 . Aydan and Ulusay (2013) also found a linear correlation for tuffs in the Cappadocia region of Turkey (Table 1). 
Table 1. Equations correlating unconfined compressive strength (UCS) or static Young's modulus ( $\left.E_{s t}\right)$ with the needle penetration index (NPI) found in previous studies.

\begin{tabular}{|c|c|c|c|c|}
\hline \multirow{2}{*}{ Authors } & \multirow{2}{*}{ Correlation function } & \multicolumn{2}{|c|}{$\begin{array}{c}\text { Measurement } \\
\text { units }\end{array}$} & \multirow{2}{*}{ Rock types } \\
\hline & & $\begin{array}{c}\text { UCS or } \\
E_{\text {st }}\end{array}$ & NPI & \\
\hline $\begin{array}{l}\text { Okada et al. } \\
\text { (1985) }\end{array}$ & $\begin{array}{l}\log \mathrm{UCS}=0.978 \cdot \log \mathrm{NPI}+1.599(\mathrm{R}= \\
0.914)(\text { Eq. } 4)\end{array}$ & $\mathrm{kg} / \mathrm{cm}^{2}$ & $\mathrm{~kg} / \mathrm{mm}$ & $\begin{array}{l}\text { Rocks and } \\
\text { soilcrete }\end{array}$ \\
\hline $\begin{array}{l}\text { Yamaguchi et } \\
\text { al. (1997) }\end{array}$ & $\begin{array}{l}\log \mathrm{UCS}=0.982 \cdot \log \mathrm{NPI}-0.209(\mathrm{R}= \\
0.872)(\mathrm{Eq} .5)\end{array}$ & $\mathrm{kg} / \mathrm{cm}^{2}$ & $\mathrm{~kg} / \mathrm{cm}$ & Pyroclastic rocks \\
\hline $\begin{array}{l}\text { Takahashi et } \\
\text { al. (1998) }\end{array}$ & $\begin{array}{l}\mathrm{UCS}=1.5395 \cdot \mathrm{NPI}^{0.9896}(\mathrm{R}=0.90)(\mathrm{Eq} . \\
6)\end{array}$ & $\mathrm{MPa}$ & $\mathrm{N} / \mathrm{mm}$ & $\begin{array}{l}\text { Sandstone, } \\
\text { siltstone, } \\
\text { conglomerate, } \\
\text { greywacke, } \\
\text { volcanic tuff }\end{array}$ \\
\hline $\begin{array}{l}\text { Naoto et al. } \\
\text { (2004) }\end{array}$ & $\mathrm{UCS}=41.8 \cdot \mathrm{NPI}-4(\mathrm{R}=0.899)(\mathrm{Eq} .7)$ & $\mathrm{kN} / \mathrm{m}^{2}$ & $\mathrm{~N} / \mathrm{cm}$ & Hard claystone \\
\hline $\begin{array}{l}\text { Uchida et al. } \\
\text { (2004) }\end{array}$ & $\mathrm{UCS}=27.3 \cdot \mathrm{NPI}+132(\mathrm{Eq} .8)$ & $\mathrm{kPa}$ & $\mathrm{N} / \mathrm{cm}$ & Sandstone \\
\hline $\begin{array}{l}\text { Erguler and } \\
\text { Ulusay (2007, } \\
\text { 2009) }\end{array}$ & $\mathrm{UCS}=0.51 \cdot \mathrm{NPI}^{0.8575}(\mathrm{R}=0.87)(\mathrm{Eq} .9)$ & $\mathrm{MPa}$ & $\mathrm{N} / \mathrm{mm}$ & $\begin{array}{l}\text { Marble, siltstone, } \\
\text { shale, tuff }\end{array}$ \\
\hline $\begin{array}{l}\text { Ulusay and } \\
\text { Erguler } \\
\text { (2012) }\end{array}$ & $\begin{array}{l}\mathrm{UCS}=0.402 \cdot \mathrm{NPI}^{0.929}(\mathrm{R}=0.89)(\mathrm{Eq} . \\
10)\end{array}$ & $\mathrm{MPa}$ & $\mathrm{N} / \mathrm{mm}$ & $\begin{array}{l}\text { Marl, tuff, shale, } \\
\text { siltstone, } \\
\text { sandstone, } \\
\text { greywacke, } \\
\text { mudstone }\end{array}$ \\
\hline \multirow[b]{2}{*}{ Aydan (2012) } & $\mathrm{UCS}=0.2 \cdot \mathrm{NPI}(\mathrm{Eq} \cdot 11)$ & $\mathrm{MPa}$ & $\mathrm{N} / \mathrm{mm}$ & \multirow{2}{*}{$\begin{array}{l}\text { Tuff, sandstone, } \\
\text { pumice, } \\
\text { limestone, lignite, } \\
\text { mudstone, } \\
\text { siltstone, marl, } \\
\text { loam }\end{array}$} \\
\hline & $\begin{array}{l}\mathrm{E}_{\mathrm{st}}=0.12 \cdot \mathrm{NPI}(\text { Upper limit) (Eq. 12.a) } \\
\mathrm{E}_{\mathrm{st}}=0.05 \cdot \mathrm{NPI}(\text { Eq. 12.b) } \\
\mathrm{E}_{\mathrm{st}}=0.015 \cdot \mathrm{NPI} \text { (Lower limit) (Eq. 12.c) }\end{array}$ & GPa & $\mathrm{N} / \mathrm{mm}$ & \\
\hline \multirow{2}{*}{$\begin{array}{l}\text { Aydan and } \\
\text { Ulusay (2013) }\end{array}$} & $\mathrm{UCS}=0.3 \cdot \mathrm{NPI}(\mathrm{Eq} \cdot 13)$ & $\mathrm{MPa}$ & $\mathrm{N} / \mathrm{mm}$ & \multirow{2}{*}{ Turkish tuffs } \\
\hline & $E_{s t}=25 \cdot N P I(E q \cdot 14)$ & $\mathrm{MPa}$ & $\mathrm{N} / \mathrm{mm}$ & \\
\hline $\begin{array}{l}\text { Kahraman et } \\
\text { al. (2017) }\end{array}$ & $\mathrm{UCS}=0.35 \cdot \mathrm{NPI}(\mathrm{Eq} \cdot 15)$ & $\mathrm{MPa}$ & $\mathrm{N} / \mathrm{mm}$ & Cayirham coal \\
\hline
\end{tabular}

Changes in the NPI produced by water content remains under-researched, with just a few papers published on this subject (Aydan, 2012; Ulusay et al., 2014). Those works, which studied the relationship between saturation and the NPI for Japanese, Turkish and Egyptian soft rocks, concluded that the NPI decreases as rock water content increases, as also do UCS and $E_{\text {st. }}$ The same authors also analysed NPI variations in line with the number of drying-wetting and thawing-freezing cycles, suggesting the possibility of using the needle penetrometer to assess rock degradation or weathering.

The PLT, in contrast, has been extensively studied, with hundreds of correlations proposed for the $I_{S(50)}$ with the UCS. However, the number of studies of soft rocks such as siltstones and gypsiferous rocks is small. Although the International Society for Rock Mechanics (ISRM) (Franklin, 1985) established that the UCS/I $I_{s(50)}$ ratio could vary from 15 to 50 due to anisotropy and the large variety of rocks, this ratio could be lower than 15 for siltstones and gypsiferous 
rocks. Along those lines, Smith (1997) determined that the UCS/I $I_{s(50)}$ ratio ranged from 8 to 15 for weak rock materials from coastal US deposits, while Sadeghiamirshahidi and Vitton (2019) suggested 6.6 to 7.7 for Michigan Basin gypsum. A summary of the UCS/I $I_{s(50)}$ ratios found in the literature for different sedimentary and soft rocks is given in Table 2.

Table 2. Unconfined compressive strength (UCS) and point load strength index $\left(\mathrm{I}_{s(50)}\right)$ ratios for sedimentary and soft rocks reported in previous studies.

\begin{tabular}{|c|c|c|}
\hline Authors & $k=U C S / I_{S(50)}$ & Rock type \\
\hline Broch \& Franklin (1972) & 24 & Several rock types (mainly sandstones) \\
\hline Bieniawski (1975) & 23 & Sandstone (South Africa) \\
\hline Carter \& Sneddon (1977) & $21-22$ & Coal measures (UK) \\
\hline Al-Jassar \& Hawkings (1979) & $17-30$ & Carboniferous limestones (UK) \\
\hline Read et al. (1980) & 16 & Several sedimentary rocks (Australia) \\
\hline ISRM \& Franklin (1985) & $20-25$ & Several rock types \\
\hline Das (1985) & $14.7-18$ & Siltstone and sandstone (Canada) \\
\hline Vallejo et al. (1989) & $12.5-17.4$ & Sandstone and shale (USA) \\
\hline Jermy \& Bell (1991) & 14.1 & Coal measures (South Africa) \\
\hline Smith (1997) & $8-15$ & Harbour dredge materials \\
\hline Hawkins (1998) & $7-68$ & Sandstones, limestones and chalks (UK) \\
\hline Rusnak \& Mark (2000) & $19.6-22.4$ & $\begin{array}{l}\text { Shale, siltstone, sandstone and limestone } \\
\text { (USA) }\end{array}$ \\
\hline Tsiambaos \& Sabatakakis (2004) & 23 & Limestone, marlstone and sandstone (Greece) \\
\hline Palchik \& Hatzor (2004) & $8-18$ & Porous chalks \\
\hline Sabatakakis et al. (2008) & $13-28$ & Marlstones, sandstones and limestones \\
\hline Diamantis et al. (2009) & 19.8 & Serpentinites (Greece) \\
\hline Tziallas et al. (2009) & 14.5 & Sedimentary and metamorphic rocks (Greece) \\
\hline \multirow[t]{2}{*}{ Singh et al. (2012) } & $21-23$ & $\begin{array}{l}\text { Harder rocks (sandstone, limestone, } \\
\text { dolomite) }\end{array}$ \\
\hline & $14-16$ & Softer rocks (Khondalite, shale, rock salt) \\
\hline Kohno \& Maeda (2012) & 16.4 & Volcaniclastic rocks (Japan) \\
\hline Li \& Wong (2013) & $19.8-21.3$ & $\begin{array}{l}\text { Meta-siltstone and meta-sandstone } \\
\text { (Singapore) }\end{array}$ \\
\hline Kahraman (2014) & 8.7 & Pyroclastic rocks (Turkey) \\
\hline Sadeghiamirshahidi \& Vitton (2019) & $6.6-7.7$ & Michigan Basin gypsum \\
\hline
\end{tabular}

Furthermore, very few papers have focused on the indirect determination of $E_{s t}$ using the $I_{s(50)}$; one was the noteworthy laboratory work carried out by Dauod et al. (2017) on Iraqi limestones and sandstones, for which a power function correlation between both parameters was determined. Another relatively unexplored topic is PLT evaluation of changes in rock properties caused by water saturation. Khono and Maeda (2012) found reductions of $15-98 \%$ in the $I_{s(50)}$ and $18.5-97.1 \%$ in UCS for several types of volcaniclastic rocks, Kahraman (2014) reported reductions of up to $37.8 \%$ in the $\mathrm{I}_{s(50)}$ and $40.4 \%$ in UCS for pyroclastic rocks, while Sadeghiamirshahidi and Vitton (2019) measured decreases of $53.6 \%$ in the $I_{s(50)}, 41.1 \%$ in UCS and $49.6 \%$ in the $E_{s t}$ for Michigan Basin gypsum. 
We attempt to go beyond the scope of previous investigations in our comparative study of the applicability of NPT and PLT to estimates of the strength and deformability of dry and saturated soft sedimentary rocks from southeastern Spain.

\section{METHODOLOGY}

\subsection{Rock block collection and specimen preparation}

Two different lithologies widely present in the province of Alicante (Spain) were studied for this research: a Neogene siltstone collected from an outcrop located in the peri-urban area of Alicante city and a Keuper Triassic gypsiferous rock extracted from an outcrop in the municipality of Finestrat (Fig. 1). For the siltstone, four homogeneous rock blocks (labelled S1 to S4) were carefully selected and visually inspected to ensure the absence of fractures, joints and areas with different degrees of weathering. For the gypsiferous rock, five blocks (labelled G1 to G5) were also meticulously selected but showing, in this case, important weathering and an intrinsic heterogeneity due to the presence of red and green clayey clasts. Also identified in the gypsiferous blocks were some Jacinto quartzes (smaller than $1 \mathrm{~cm}$ ).

Each of the nine blocks was large enough to extract the specimens necessary to carry out all mechanical test types (Fig. 1). To carry out the NPT according to the ISRM-suggested method (Ulusay et al., 2014), from each block, four cylindrical core specimens, $52 \mathrm{~mm}$ in diameter and 50-55 mm in length, were drilled perpendicular to bedding using a diamond drill rig. Additionally, to carry out the PLT, drilled from each block was a minimum of sixteen cylindrical core specimens, $28 \mathrm{~mm}$ in diameter and 70-75 mm in length. Finally, to calculate UCS and $\mathrm{E}_{\mathrm{st}}$, drilled from each block was a minimum of eight cylindrical core specimens, $28 \mathrm{~mm}$ in diameter and 70 $75 \mathrm{~mm}$ in length to ensure a minimum slenderness (diameter:length) ratio of 2.5 for the UCS test, as required by various standards (ISRM, 1977; AENOR, 1990a).

To prepare dry and fully saturated specimens for each block/test and achieve the necessary constant final mass, half of the specimens were dried in an oven at $50^{\circ} \mathrm{C}$ and the other half were soaked in water in a vacuum chamber. That is, at certain time intervals, the specimens were removed from the oven or the saturation chamber, weighed and immediately reintroduced in them until a constant mass was reached. Specifically, the immersion time necessary for full water saturation was less than 48 hours in this type of rocks. 


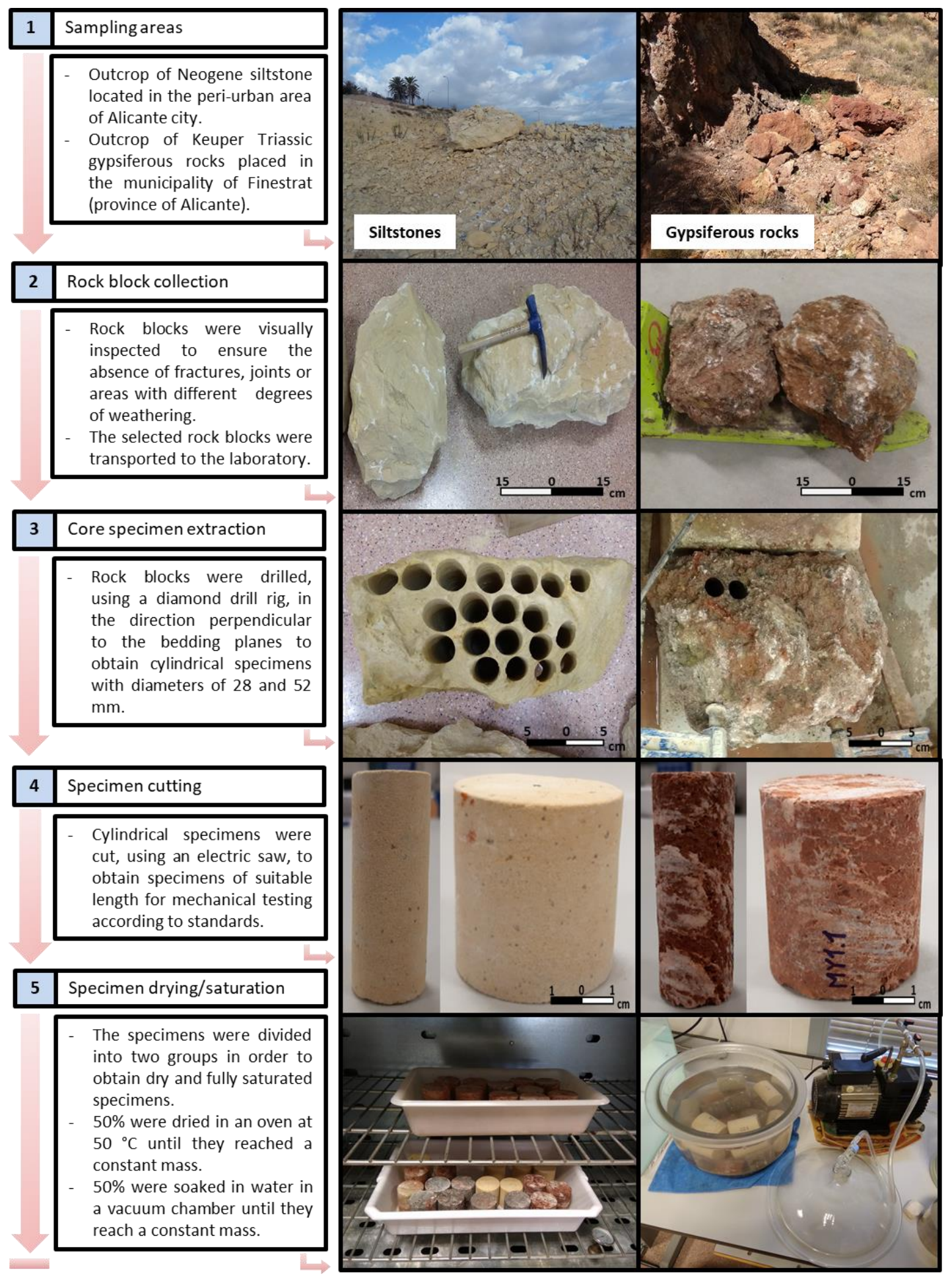

Figure 1. Rock block collection and specimen preparation.

\subsection{Test procedures}

\subsubsection{Chemical and mineralogical analyses}

To study how chemical and mineral composition and water saturation weakened the strength of the selected rocks, we performed the following analyses: thin-section petrographic analysis, using an OPTIKA B600POL petrographic microscope with the X4 objective lens; carbonate content determination, using a Bernard calcimeter according to UNE 103-200-93 (AENOR, 1993); 
X-ray fluorescence (XRF), conducted using a PHILIPS MAGIX PRO X-ray sequential spectrometer equipped with a rhodium $\mathrm{X}$-ray tube and beryllium window and a single goniometer-based measuring channel covering the complete measurement range, according to ASTM E1621-13 (E1621-13, 2013); and, finally, X-ray diffraction (XRD), conducted using a Bruker D8-Advance XRay diffractometer with a KRISTALLOFLEX K 760-80F X-ray generator and XR tube with a copper anode.

\subsubsection{Physical properties}

Dry and saturated bulk densities ( $\rho_{d}$ and $\rho_{\text {sat }}$ ) were calculated, according to UNE-EN 1936 (AENOR, 2007), by dividing the specimen's dry or saturated weight by the specimen's bulk volume, calculated from diameter and length measured using a Vernier caliper. True density $\left(\rho_{r}\right)$ was determined using the pycnometer method in accordance with UNE 103-302-94 (AENOR, 1994).

Open porosity $\left(p_{0}\right)$ was measured using specimen dry, submerged and saturated weights and specimen volume according to UNE-EN 1936 (AENOR, 2007). Total porosity (p) was computed from rock dry density and true density (AENOR, 2007). Water absorption $\left(\mathrm{W}_{\mathrm{a}}\right.$ ) was calculated as the ratio between the saturated mass after immersion for 48 hours and the dry mass of the specimens, according to UNE-EN 13755 (AENOR, 2008).

Pore-size distribution and, hence, rock porosity, was measured using the mercury intrusion porosimetry (MIP) technique: one MIP test for the siltstone and 3 MIP tests for the gypsiferous rock (due to its greater heterogeneity).

\subsubsection{Mechanical properties}

A servo-controlled press with a capacity of $200 \mathrm{kN}$ (MUF-401 Servosis) was used to carry out the strength and deformability tests. Specimen strain was measured using a specific instrument consisting of two joined metal rings positioned in parallel along the specimen axis and two diametrically opposed linear variable differential transducers that recorded changes in the axial relative distance between rings during unloading-reloading cycles. Axial strain was measured up to a maximum value equal to $50 \%$ of the failure load of specimens in order to obtain the secant $\mathrm{E}_{\text {st }}$ according to UNE 22950-3 (AENOR, 1990b). Once the deformability test was concluded, the rings were removed from the specimen and the loading tests were repeated until failure. The loading rate was adjusted to make sure that specimen failure in dry and saturated states happened between 5 and 10 minutes after starting the test, as required by UNE 22950-1 (AENOR, 1990a).

The PLT was performed using a digital device (45-D0550 Controls) that diametrically tested the core specimens. Size correction was applied to calculate the $I_{s(50)}$ in accordance with the ISRM standard (Franklin, 1985).

The NPT, using the device developed by Maruto Co. (2006), was performed five times for each specimen surface, under the premise that each penetration point was at least $10 \mathrm{~mm}$ from any other point, according to the ISRM (Ulusay et al., 2014) (Fig. 2). The NPI was then calculated as follows:

$$
\text { For } \mathrm{F}=100 \mathrm{~N} \text { and } \mathrm{D} \leq 10 \mathrm{~mm}, \mathrm{NPI}=\frac{100}{\mathrm{D}} \text { (Eq. 16.a) }
$$




$$
\text { For } \mathrm{D}=10 \mathrm{~mm} \text { and } \mathrm{F}<100 \mathrm{~N}, \mathrm{NPI}=\frac{\mathrm{F}}{10} \quad(\mathrm{Eq} .16 . \mathrm{b})
$$

where $\mathrm{F}$ is the applied load (in $\mathrm{N}$ ) and $\mathrm{D}$ is the penetration depth (in $\mathrm{mm}$ ).

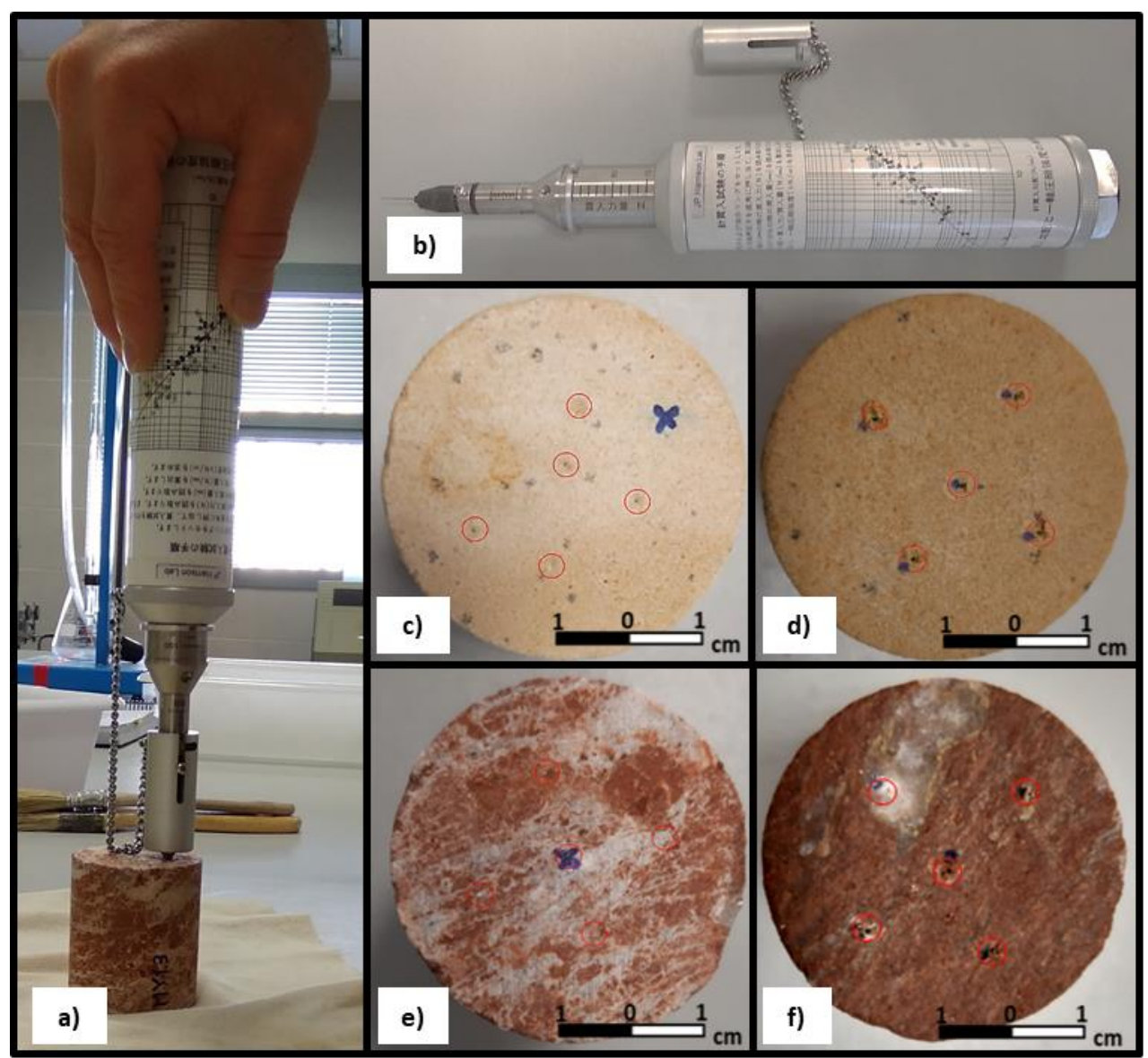

Figure 2. a) Needle penetration test (NPT). b) Needle penetrometer used in this work. c) and d) Dry and saturated siltstone specimens, respectively, after NPT. e) and f) Dry and saturated gypsiferous rock specimens, respectively, after NPT. The circles indicate the points where testing was done.

\section{RESULTS}

\subsection{Chemical and mineralogical composition}

XRF analyses showed that the main chemical compounds in the siltstone were $\mathrm{CaO}(44 \%)$ and $\mathrm{SiO}_{2}(8 \%)$, with loss on ignition (LOI) of $44 \%$, while the main chemical compounds in gypsiferous rock were $\mathrm{SO}_{3}(36-42 \%), \mathrm{CaO}(27-35 \%), \mathrm{SiO}_{2}(7-8 \%)$ and $\mathrm{MgO}$ (3-7\%), with LOI of 3-20\% (Table 3). XRD revealed that calcite and quartz were the main minerals in the siltstone, while gypsum, bassanite, dolomite and quartz were the dominant minerals in the gypsiferous rock (Fig. 3). Small amounts of clay (aluminosilicates) were also found in both lithologies. 
Table 3. Chemical composition (\% oxides) for siltstone (S2) and gypsiferous rock (G1, G3 and G5) obtained by XRF analyses.

\begin{tabular}{|c|c|c|c|c|}
\cline { 2 - 5 } \multicolumn{1}{c|}{} & $\mathrm{S} 2$ & $\mathrm{G} 1$ & $\mathrm{G} 3$ & $\mathrm{G} 5$ \\
\hline Compound & $(\%)$ & $(\%)$ & $(\%)$ & $(\%)$ \\
\hline $\mathrm{Na}_{2} \mathrm{O}$ & 0.24 & 0.41 & 0.22 & - \\
\hline $\mathrm{MgO}$ & 0.73 & 3.84 & 7.20 & 3.44 \\
\hline $\mathrm{Al}_{2} \mathrm{O}_{3}$ & 0.79 & 1.78 & 2.14 & 2.37 \\
\hline $\mathrm{SiO}_{2}$ & 8.13 & 6.86 & 8.29 & 8.42 \\
\hline $\mathrm{P}_{2} \mathrm{O}_{5}$ & - & - & - & 0.05 \\
\hline $\mathrm{SO}_{3}$ & 0.25 & 41.51 & 42.08 & 36.14 \\
\hline $\mathrm{K}_{2} \mathrm{O}$ & 0.26 & 0.27 & 0.33 & 0.71 \\
\hline $\mathrm{CaO}$ & 44.34 & 32.30 & 34.85 & 26.67 \\
\hline $\mathrm{TiO}_{2}$ & 0.04 & 0.13 & 0.09 & 0.18 \\
\hline $\mathrm{Fe} \mathrm{O}_{3}$ & 0.56 & 1.16 & 1.16 & 1.07 \\
\hline $\mathrm{SrO}^{2}$ & 0.14 & 0.35 & 0.61 & 0.31 \\
\hline $\mathrm{I}$ & - & 0.02 & - & - \\
\hline $\mathrm{BaO}$ & - & 0.21 & 0.08 & 0.13 \\
\hline $\mathrm{WO}_{3}$ & 0.10 & 0.15 & 0.15 & 0.12 \\
\hline $\mathrm{LOI}$ & 44.42 & 11.01 & 2.79 & 20.40 \\
\hline
\end{tabular}

In line with above-mentioned results, Bernard calcimeter tests revealed that carbonate content was $92-94 \%$ for the siltstone and $1-4 \%$ for the gypsiferous rock.

a)

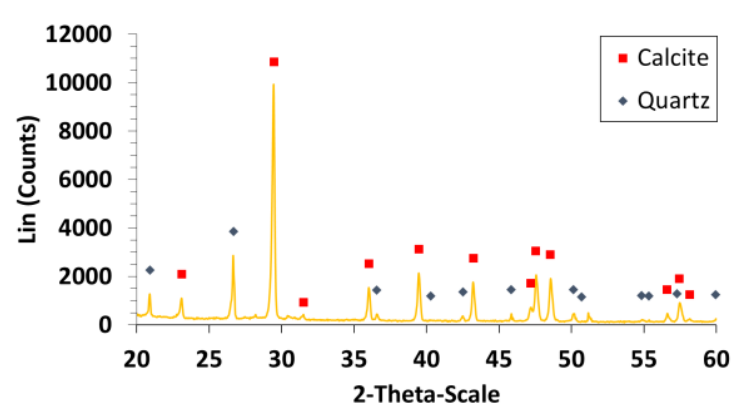

C) X-ray powder diffractogram of Gypsiferous rock $G 3$

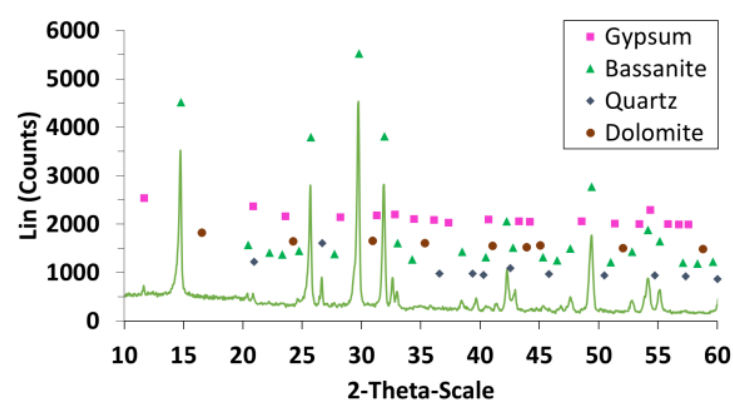

b) X-ray powder diffractogram of Gypsiferous rock G1

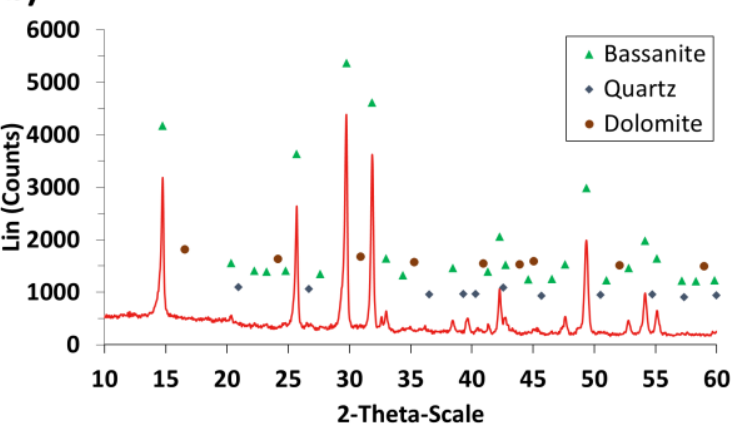

d) X-ray powder diffractogram of Gypsiferous rock G5

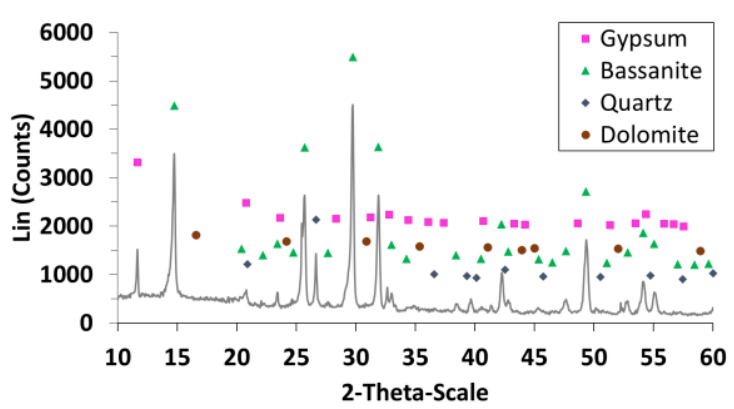

Figure 3. XRD analyses of siltstone (S2) (a) and gypsiferous rock (G1, G3 and G5) (b, c and d, respectively).

From a petrographic point of view, the siltstone had a grain size of $0.01-0.5 \mathrm{~mm}$, mostly calcite and quartz (monocrystalline and polycrystalline) minerals but also some phyllosilicates (Fig. 4.a). 
As for the gypsiferous rock, factures were filled mainly with laminar microcrystalline gypsum and, to a lesser extent, fibrous gypsum. The gypsum crystals exhibited several morphologies and sizes $(50 \mu \mathrm{m}-3 \mathrm{~mm})$ and sometimes showed exfoliation. Also identified, in addition to bassanite, dolomite and anhydritic and detritic levels formed of monocrystalline and polycrystalline quartz, were calcite crystals and fragments of carbonate rock (Fig. 4.b, 4.c and 4.d).
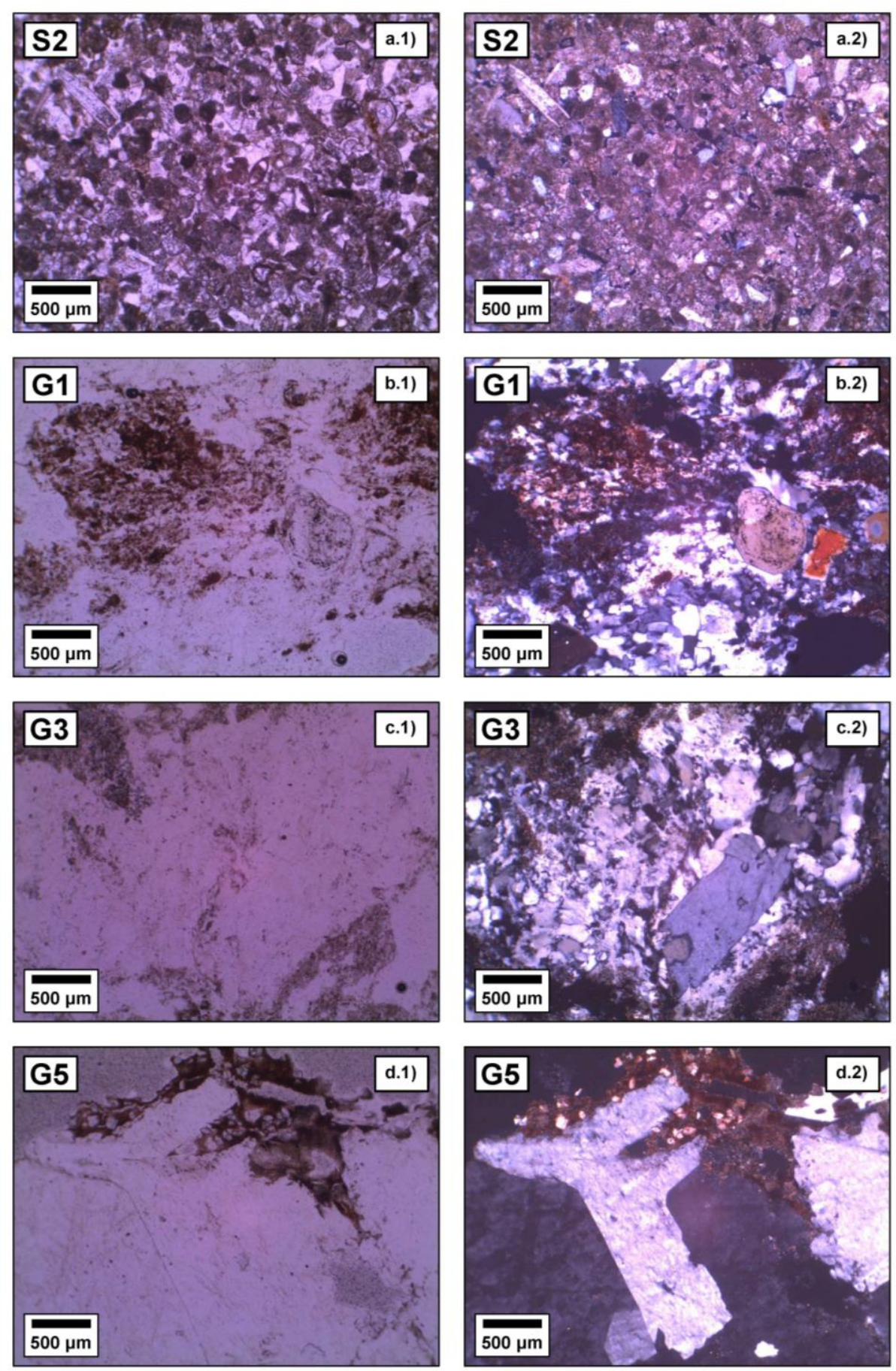

Figure 4. Thin-section microphotographs of siltstone (S2) and gypsiferous rock (G1, G3 and G5) taken with parallel light (a.1, b.1, c.1 and d.1) and crossed nicols (a.2, b.2, c.2 and d.2). 


\subsection{Physical properties}

Dry and saturated bulk densities of the siltstone specimens (rock blocks S1 to S4) varied between 1.88 and $1.94 \mathrm{~g} / \mathrm{cm}^{3}$ and 2.19 and $2.23 \mathrm{~g} / \mathrm{cm}^{3}$, respectively, with the highest and lowest bulk density values corresponding to the S3 and S2 specimens, respectively. As for porosity, the S3 specimens had the lowest mean open and total porosity values ( 26.34 and $26.62 \%$, respectively) and lowest mean water absorption value (13.39\%), while the S2 specimens had the highest mean open porosity, total porosity and water absorption values $(28.83,29.29$ and $15.11 \%$, respectively). S1 and S4 specimens had mean density and porosity values close to the S2 and S3 specimens, respectively.

As for the gypsiferous rock specimens (rock blocks G1 to G5), all blocks exhibited greater densities and lower porosities than the siltstones and also showed wider ranges because of their greater heterogeneity. Dry and saturated bulk densities varied between 2.03 and $2.23 \mathrm{~g} / \mathrm{cm}^{3}$ and 2.19 and $2.28 \mathrm{~g} / \mathrm{cm}^{3}$, respectively, with the highest and lowest bulk density values corresponding to the G4 and G1 specimens, respectively. G4 specimens also had the lowest mean open and total porosity values ( 3.22 and $9.32 \%$, respectively) and water absorption value (1.45\%), while the $\mathrm{G} 1$ specimens had the greatest mean open porosity, total porosity and water absorption values (10.64, 13.72 and $5.12 \%$, respectively). G2 and G3 specimens had similar mean density and porosity values.

The physical properties corresponding to the nine rock blocks, as obtained using traditional techniques, are summarized in Table 4.

Table 4. Physical properties of the siltstone and gypsiferous rock blocks. $\rho_{d}$ : dry density; $\rho_{\text {sat }}$ : saturated density; $p_{o}$ : open porosity; $p$ : total porosity; $W_{a}$ : water absorption; $\chi$ : mean value; $\sigma$ : standard deviation.

\begin{tabular}{|c|c|c|c|c|c|}
\hline \multirow{2}{*}{$\begin{array}{l}\text { Rock } \\
\text { block }\end{array}$} & \multicolumn{5}{|c|}{ Physical properties $(\chi \pm \sigma)$} \\
\hline & $\begin{array}{c}\rho_{d} \\
\left(\mathrm{~g} / \mathrm{cm}^{3}\right)\end{array}$ & $\begin{array}{l}p_{o} \\
\text { (\%) }\end{array}$ & $\begin{array}{c}\rho_{\text {sat }} \\
\left(\mathrm{g} / \mathrm{cm}^{3}\right)\end{array}$ & $\begin{array}{c}p \\
(\%)\end{array}$ & $\begin{array}{l}W_{a} \\
(\%)\end{array}$ \\
\hline S1 & $1.880 \pm 0.016$ & $28.45 \pm 0.36$ & $2.200 \pm 0.007$ & $28.91 \pm 0.46$ & $14.81 \pm 0.27$ \\
\hline S2 & $1.877 \pm 0.020$ & $28.83 \pm 1.06$ & $2.193 \pm 0.020$ & $29.29 \pm 1.08$ & $15.11 \pm 0.81$ \\
\hline S3 & $1.937 \pm 0.039$ & $26.34 \pm 1.28$ & $2.227 \pm 0.021$ & $26.62 \pm 1.34$ & $13.39 \pm 0.88$ \\
\hline S4 & $1.933 \pm 0.042$ & $26.85 \pm 0.82$ & $2.219 \pm 0.012$ & $27.31 \pm 0.67$ & $13.73 \pm 0.56$ \\
\hline G1 & $2.035 \pm 0.073$ & $10.64 \pm 2.73$ & $2.194 \pm 0.025$ & $13.72 \pm 2.32$ & $5.12 \pm 1.41$ \\
\hline G2 & $2.157 \pm 0.038$ & $6.14 \pm 1.76$ & $2.268 \pm 0.025$ & $9.95 \pm 2.19$ & $2.79 \pm 0.85$ \\
\hline G3 & $2.148 \pm 0.036$ & $7.16 \pm 1.16$ & $2.248 \pm 0.009$ & $11.30 \pm 0.98$ & $3.29 \pm 0.56$ \\
\hline G4 & $2.232 \pm 0.090$ & $3.22 \pm 1.84$ & $2.280 \pm 0.021$ & $9.32 \pm 2.72$ & $1.45 \pm 0.85$ \\
\hline G5 & $2.196 \pm 0.073$ & $4.67 \pm 2.74$ & $2.248 \pm 0.007$ & $10.37 \pm 3.03$ & $2.14 \pm 1.28$ \\
\hline
\end{tabular}

Regarding the porous structure of rocks as estimated by means of MIP tests, the siltstones had pore diameters in the range 0.2-60 $\mu \mathrm{m}$ (mainly 0.9-30 $\mu \mathrm{m}$ ) and intraparticle and interparticle porosity of around 8 and $22 \%$, respectively (total porosity was close to $30 \%$ ), while surface area was close to $1.1 \mathrm{~m}^{2} / \mathrm{g}$. The gypsiferous rock showed a wider range of values than the siltstones. Pore diameters were mostly in the interval 1-40 $\mu \mathrm{m}$, although some specimens had a significant number of pores with diameters of 0.004-0.02 $\mu \mathrm{m}$. Interparticle and intraparticle porosity values were $2.6-7.7 \%$ and $2.2-4.3 \%$, respectively (total porosity was $5.6-12.0 \%$ ), while surface area, at 2.5 to $3.8 \mathrm{~m}^{2} / \mathrm{g}$, was substantially higher than for the siltstone (Fig. 5). 

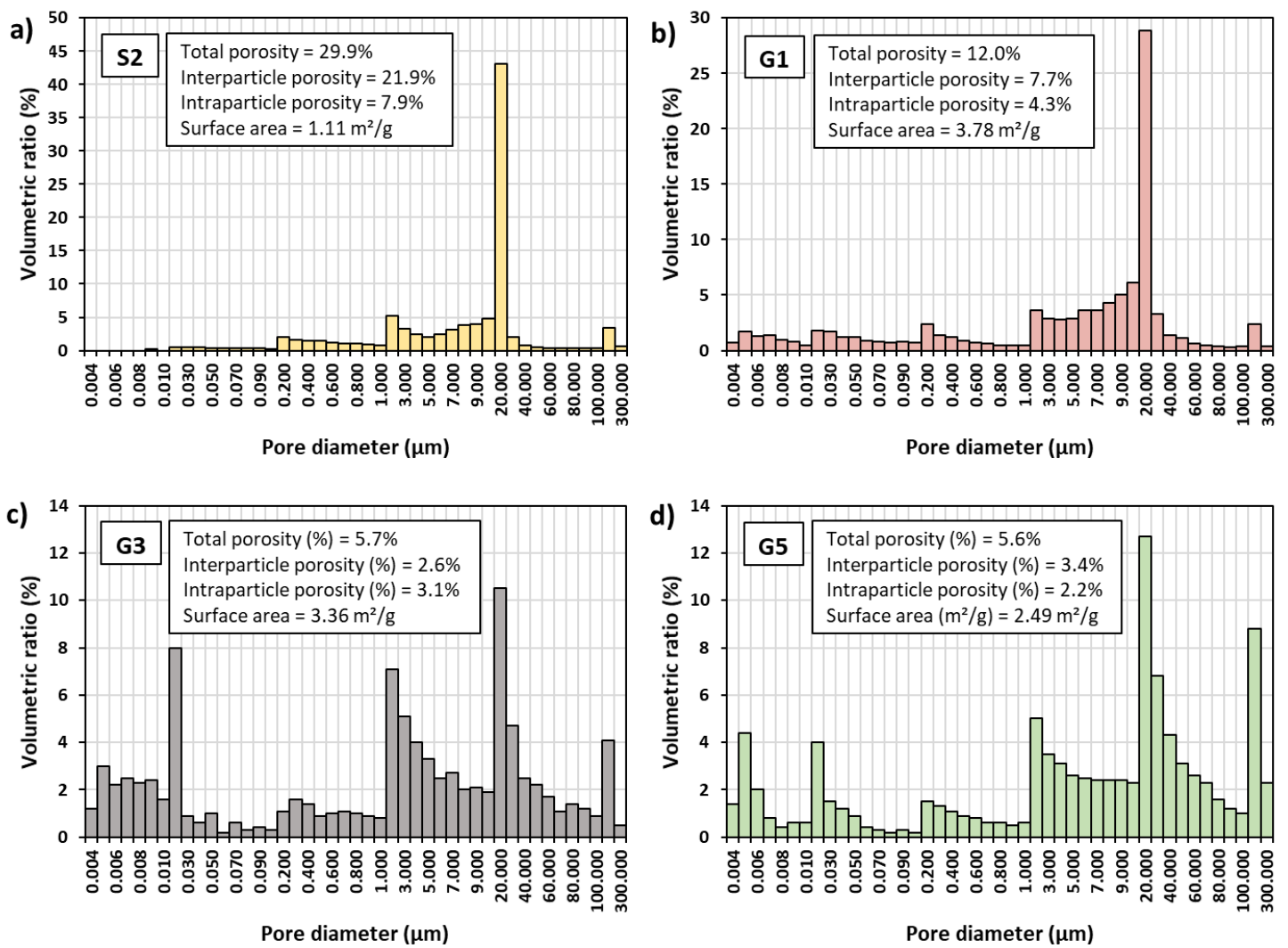

Figure 5. Variations in volumetric ratios, as measured using mercury intrusion porosimetry, according to pore size distribution in siltstone block S2 (a) and gypsiferous blocks G1, G3 and G5 (b, c and d, respectively).

\subsection{Mechanical properties}

According to Agustawijaya (2007), the kind of siltstone and gypsiferous rock studied in this work can be classified as soft (or weak) rock since their UCS values are lower than $20 \mathrm{MPa}$.

For the siltstone specimens in dry conditions, the highest UCS, $I_{s(50)}, N P I$ and $E_{s t}$ values 10.84 MPa, 0.75 MPa, 93 N/mm and 4.94 GPa, respectively - were found for block S3, while the lowest UCS, $I_{s(50)}, \mathrm{NPI}$ and $\mathrm{E}_{s t}$ values were found for block $\mathrm{S} 1$, with values of $7.70 \mathrm{MPa}, 0.43 \mathrm{MPa}$, $52 \mathrm{~N} / \mathrm{mm}$ and $2.38 \mathrm{GPa}$, respectively. These results are consistent with the higher density and lower porosity of the S3 specimens and the lower density and higher porosity of the S1 specimens. As for the other siltstone blocks, $S 2$ (with UCS, $I_{s(50)}, N P I$ and $E_{s t}$ values of $8.10 \mathrm{MPa}$, $0.48 \mathrm{MPa}, 57 \mathrm{~N} / \mathrm{mm}$ and $2.84 \mathrm{GPa}$, respectively) was similar to S1, while S4 (with UCS, $\mathrm{I}_{s(50)}$, NPI and $E_{s t}$ values of $9.54 \mathrm{MPa}, 0.69 \mathrm{MPa}, 67 \mathrm{~N} / \mathrm{mm}$ and $4.91 \mathrm{GPa}$, respectively) was similar to S3. For the siltstone specimens in saturated conditions, the highest mechanical parameter values were found in S4 followed by S3 while the lowest values were found in S2 followed by S1.

As for gypsiferous rock specimens in dry conditions, the remarkable heterogeneity of this lithology resulted in great variations between specimens from the same gypsiferous rock block. In comparison to the dry siltstone specimens, these specimens had much higher $\mathrm{E}_{\text {st }}$ values (8.10$20.94 \mathrm{GPa})$ and slightly higher UCS (7.67-14.47 MPa), $\mathrm{I}_{(50)}(0.42-0.90 \mathrm{MPa})$ and NPI (59$109 \mathrm{~N} / \mathrm{mm}$ ) values. For gypsiferous rock specimens in saturated conditions, the UCS, $1_{s(50)}, \mathrm{NPI}$ and $E_{s t}$ values were 2.29-6.89 $\mathrm{MPa}, 0.26-0.71 \mathrm{MPa}, 22-66 \mathrm{~N} / \mathrm{mm}$ and 4.78-15.83 GPa, respectively. 
The mechanical properties for the nine rock blocks in dry and saturated conditions are summarized in Table 5.

Table 5. Unconfined compressive strength (UCS), static Young's modulus $\left(E_{s t}\right)$, point load strength index $\left(I_{s(50)}\right)$ and needle penetration index (NPI) values for dry and saturated rock block specimens. $\chi$ : mean value; $\sigma$ : standard deviation.

\begin{tabular}{|c|c|c|c|c|c|c|c|c|}
\hline \multirow{3}{*}{$\begin{array}{l}\text { Rock } \\
\text { block }\end{array}$} & \multicolumn{8}{|c|}{ Mechanical properties $(\chi \pm \sigma)$} \\
\hline & \multicolumn{4}{|c|}{ Dry specimens } & \multicolumn{4}{|c|}{ Saturated specimens } \\
\hline & $\begin{array}{l}\text { UCS } \\
\text { MPa }\end{array}$ & $\begin{array}{c}\mathrm{E}_{\mathrm{st}} \\
\mathrm{GPa}\end{array}$ & $\begin{array}{l}\mathrm{I}_{s(50)} \\
\mathrm{MPa}\end{array}$ & $\begin{array}{c}\text { NPI } \\
\mathrm{N} / \mathrm{mm}\end{array}$ & $\begin{array}{l}\text { UCS } \\
\text { MPa }\end{array}$ & $\begin{array}{c}\mathrm{E}_{\mathrm{st}} \\
\mathrm{GPa}\end{array}$ & $\begin{array}{l}\mathrm{I}_{s(50)} \\
\mathrm{MPa}\end{array}$ & $\begin{array}{c}\text { NPI } \\
\mathrm{N} / \mathrm{mm}\end{array}$ \\
\hline S1 & $7.70 \pm 0.44$ & $2.38 \pm 0.55$ & $0.43 \pm 0.18$ & $52 \pm 7$ & $2.89 \pm 0.76$ & $1.23 \pm 0.33$ & $0.24 \pm 0.05$ & $25 \pm 2$ \\
\hline S2 & $8.10 \pm 0.48$ & $2.84 \pm 0.63$ & $0.48 \pm 0.14$ & $57 \pm 8$ & $2.79 \pm 0.61$ & $0.91 \pm 0.29$ & $0.22 \pm 0.06$ & $21 \pm 3$ \\
\hline S3 & $10.84 \pm 2.14$ & $4.94 \pm 1.63$ & $0.75 \pm 0.11$ & $93 \pm 15$ & $5.14 \pm 1.67$ & $1.81 \pm 0.92$ & $0.42 \pm 0.10$ & $32 \pm 5$ \\
\hline S4 & $9.54 \pm 2.63$ & $4.91 \pm 0.37$ & $0.69 \pm 0.24$ & $67 \pm 21$ & $5.23 \pm 0.66$ & $2.34 \pm 0.16$ & $0.46 \pm 0.22$ & $32 \pm 3$ \\
\hline G1 & $7.67 \pm 3.35$ & $10.59 \pm 5.55$ & $0.54 \pm 0.12$ & $74 \pm 12$ & $2.29 \pm 1.06$ & $8.45 \pm 0.85$ & $0.26 \pm 0.06$ & $30 \pm 6$ \\
\hline G2 & $8.83 \pm 1.47$ & $8.10 \pm 1.43$ & $0.42 \pm 0.13$ & $59 \pm 27$ & $3.28 \pm 1.24$ & $4.78 \pm 3.52$ & $0.34 \pm 0.05$ & $38 \pm 19$ \\
\hline G3 & $9.50 \pm 0.81$ & $11.19 \pm 1.65$ & $0.59 \pm 0.12$ & $70 \pm 19$ & $2.71 \pm 0.76$ & $5.51 \pm 3.75$ & $0.39 \pm 0.06$ & $22 \pm 4$ \\
\hline G4 & $14.47 \pm 6.45$ & $20.94 \pm 9.63$ & $0.90 \pm 0.41$ & $109 \pm 3$ & $5.38 \pm 3.42$ & $13.29 \pm 3.56$ & $0.53 \pm 0.47$ & $37 \pm 6$ \\
\hline G5 & $12.03 \pm 3.97$ & $19.98 \pm 12.19$ & $0.83 \pm 0.39$ & $91 \pm 19$ & $6.89 \pm 2.52$ & $15.83 \pm 2.89$ & $0.71 \pm 0.23$ & $66 \pm 35$ \\
\hline
\end{tabular}

\subsection{NPI, $E_{s t}, U C S$ and $I_{s(50)}$ variations according to water saturation}

For the siltstone, findings regarding the influence of water saturation indicated a very high drop in NPI values in all specimens when saturated, with the highest decreases occurring in the S2 and S3 specimens (63.9 and 65.8\%, respectively), and the lowest reductions measured in the S1 and $\mathrm{S} 4$ specimens ( 51.7 and $52.5 \%$, respectively). Similar changes were observed for the $E_{s t}$, with the highest decreases measured in the S2 and S3 specimens (68.0 and 63.4\%, respectively) and the lowest reductions occurring in the S1 and S4 specimens ( 48.3 and $52.4 \%$, respectively). Regarding UCS, the results showed significant losses; the highest and lowest reductions were found for the S2 and S4 specimens (65.5 and 45.1\%, respectively), with intermediate values obtained for the S1 and S3 specimens (62.4 and 52.5\%). The order in losses was the same for the $\mathrm{I}_{\mathrm{s}(50)}$, i.e., $53.6 \%$ for $\mathrm{S} 2,44.9 \%$ for $\mathrm{S} 1,43.2 \%$ for $\mathrm{S} 3$ and $34.0 \%$ for $\mathrm{S} 4$.

As for the effect of water saturation on the gypsiferous rock, the findings also pointed to important losses for the NPI (27.0-69.1\%), UCS (42.7-71.5\%), $\mathrm{E}_{s t}(20.2-50.8 \%)$ and $\mathrm{I}_{\mathrm{s}(50)}$ (14.1$52.3 \%$ ). The highest and lowest NPI, UCS, and $E_{s t}$ reductions were measured for G3 and G5 specimens, respectively. As for $\mathrm{I}_{s(50)}$, the highest and lowest values were found for $\mathrm{G} 1$ and $\mathrm{G} 5$, respectively.

Variations in the mechanical properties measured for all nine rock blocks due to water saturation are plotted in Fig. 6.

For the siltstones, the average reduction in the NPI due to water saturation was very similar to that of the UCS and $E_{s t}$, while the $I_{s(50)}$ reduction was slightly lower. This would suggest that the $\mathrm{NPI}$ is an appropriate index to determine the effect of water on siltstone strength and deformability, as it shows greater sensitivity in measuring water content changes than $I_{s(50)}$. While the same conclusion is broadly true for gypsiferous blocks, the greater heterogeneity of this lithology introduces bias in the estimation of the parameters. 

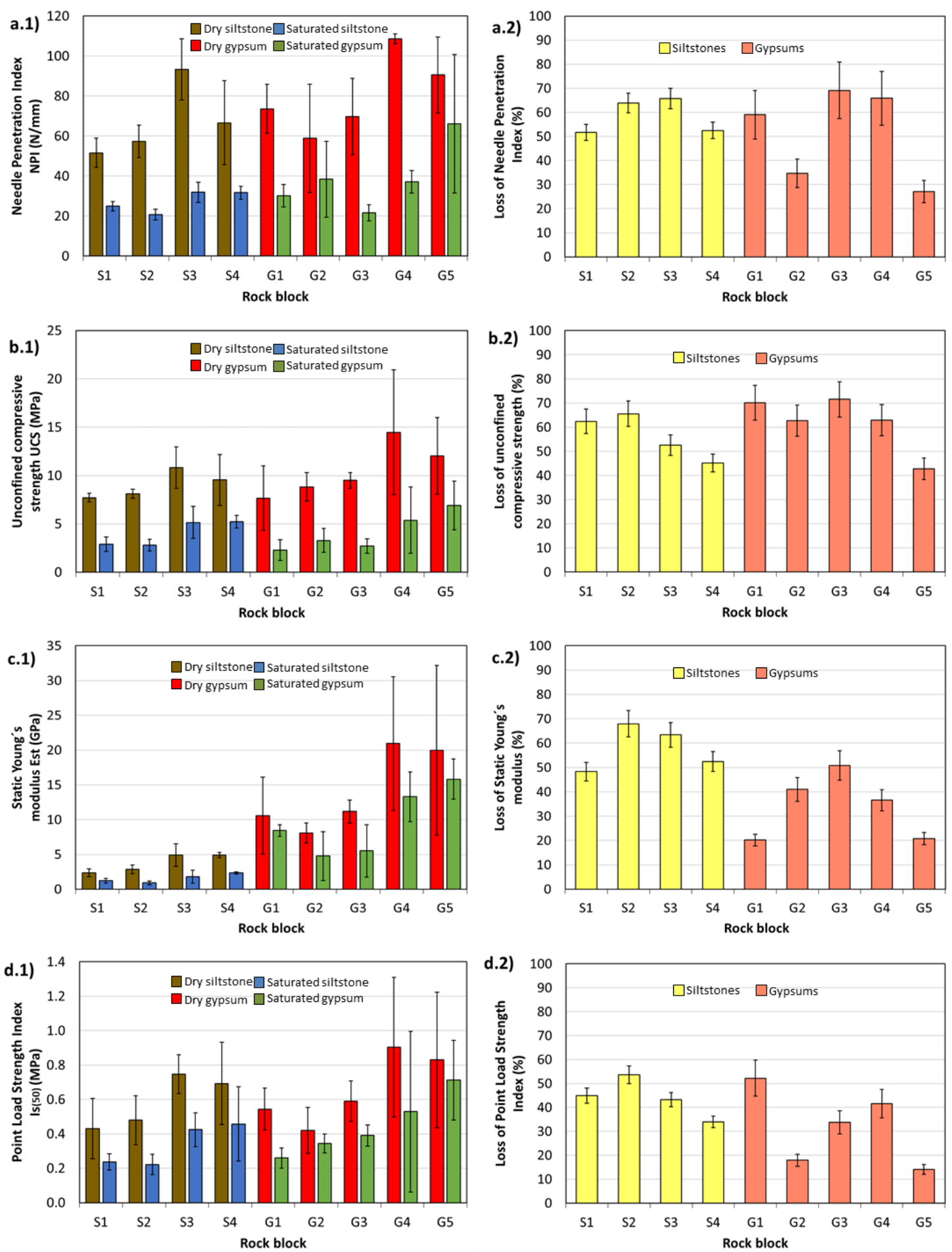

Figure 6. Influence of water saturation. Left, comparison of values for the needle penetration index (NPI)

(a.1), unconfined compressive strength (UCS) (b.1), static Young's modulus ( $\left.E_{s t}\right)$ (c.1) and point load strength index $\left(\mathrm{I}_{\mathrm{s}(50)}\right)(\mathrm{d} .1)$ measured for each block in dry and saturated conditions. Right, comparison of percentage changes in NPI (a.2), UCS (b.2), $\mathrm{E}_{\mathrm{st}}(\mathrm{c} .2)$ and $\mathrm{I}_{\mathrm{s}(50)}(\mathrm{d} .2)$.

In Sections 4.5 to 4.9 below, to identify significant correlations ( $\mathrm{P}$-value $<0.05)$ between paired combinations of NPI, UCS, $I_{s(50)}$ and $E_{s t}$ values, we investigate linear, power, exponential and logarithmic curve fits using regression analyses. 


\subsection{NPI and UCS correlations}

The results of the regression analysis to evaluate UCS and NPI correlations for siltstone and gypsiferous rock pointed to significant power and linear correlation functions. Specifically, the best coefficients of determination $\left(R^{2}\right)$ were obtained for the following through-the-origin linear functions:

For dry and saturated siltstones:

$$
\mathrm{UCS}=0.13389 \cdot \mathrm{NPI}\left(\mathrm{R}^{2}=0.9854\right)(\text { Eq. 17.a) }
$$

For dry and saturated gypsiferous rocks:

$$
\mathrm{UCS}=0.12559 \cdot \mathrm{NPI}\left(\mathrm{R}^{2}=0.9804\right)(\mathrm{Eq} .17 . \mathrm{b})
$$

where NPI and UCS are expressed in N/mm and MPa, respectively. Although in our case, the slope of the regression lines was lower than reported in the literature, the functions are quite similar (Fig. 7), indicating that, for siltstone and gypsiferous rock, we obtained higher NPI values (i.e., lower penetration depths) than obtained by other authors for rocks with similar UCS values. Apart from the peculiarities of the tested rocks, this difference of slope could be due to the NPT involves not only the UCS but also at other intrinsic parameters of rock.
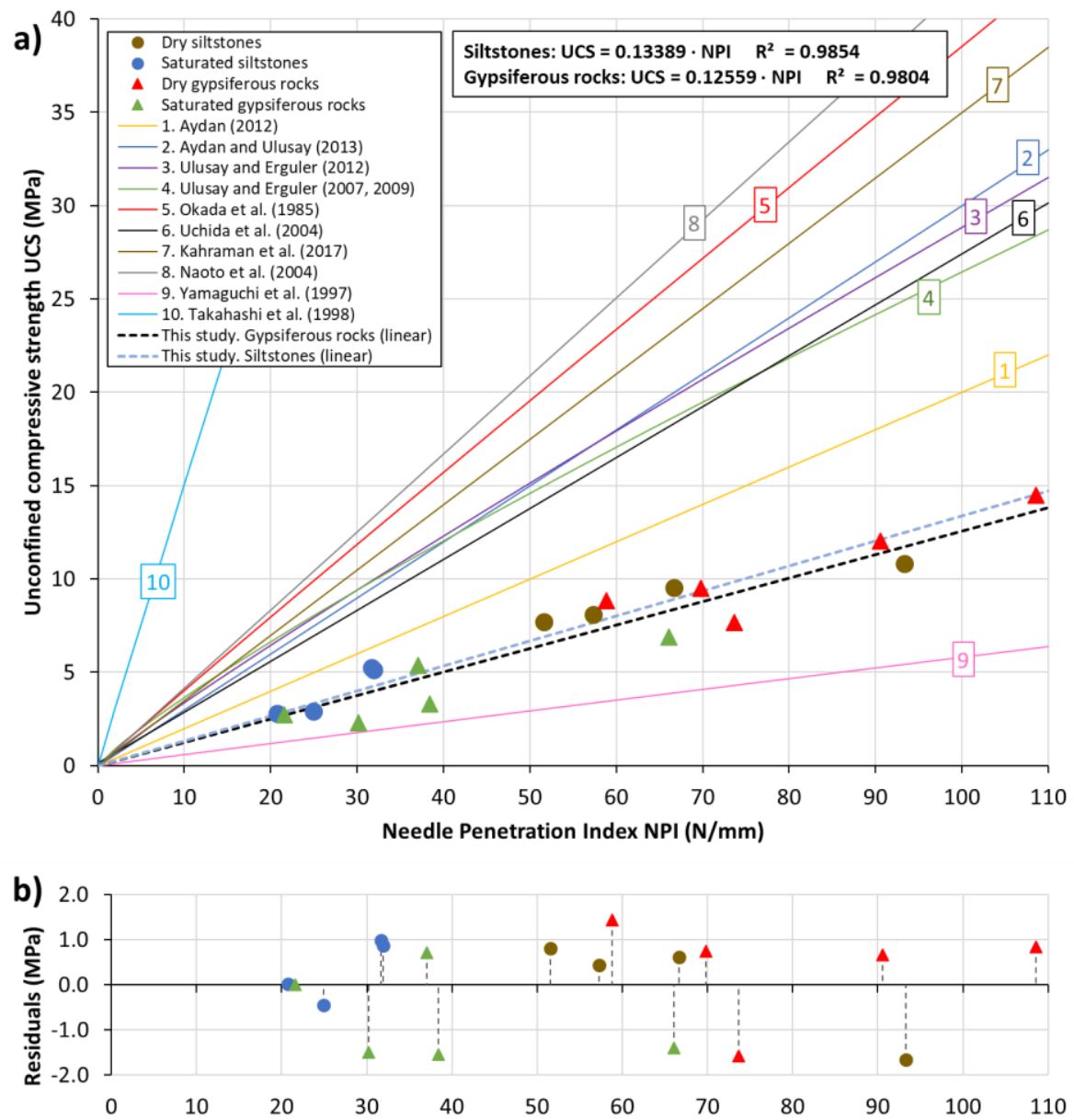

Figure 7. (a) Needle penetration index (NPI) and unconfined compressive strength (UCS) correlations for dry and saturated siltstone and gypsiferous rock compared to functions reported in published studies.

(b) Plotted residuals. 


\section{6. $\mathrm{NPI}$ and $\mathrm{E}_{\mathrm{st}}$ correlations}

The results of the regression analysis to predict values of $E_{\text {st }}$ from the NPI for siltstone and gypsiferous rock pointed to significant linear and power functions for both lithologies. The best coefficients of determination were obtained, however, by fitting through-the-origin linear functions, as follows:

For dry and saturated siltstones:

$$
E_{\text {st }}=0.05658 \cdot N P I \quad\left(R^{2}=0.9691\right)(E q .18 . a)
$$

For dry and saturated gypsiferous rocks:

$$
E_{\text {st }}=0.19405 \cdot \operatorname{NPI}\left(R^{2}=0.9422\right)(\text { Eq. 18.b) }
$$

where NPI and $E_{s t}$ are expressed in N/mm and GPa, respectively. The $R^{2}$ value for gypsiferous rock (0.94) was slightly lower than for siltstone (0.97), probably due to the greater differences among the gypsiferous rock specimens than among the siltstone specimens.

For the siltstone, the fitting function was very similar to those proposed by Aydan (2012) and Aydan and Ulusay (2013) for Turkish rocks (Fig. 8), whereas for the gypsiferous rock, we obtained lower NPI values (i.e., greater penetration depths) than obtained by them for rocks with similar $E_{\text {st }}$ values.
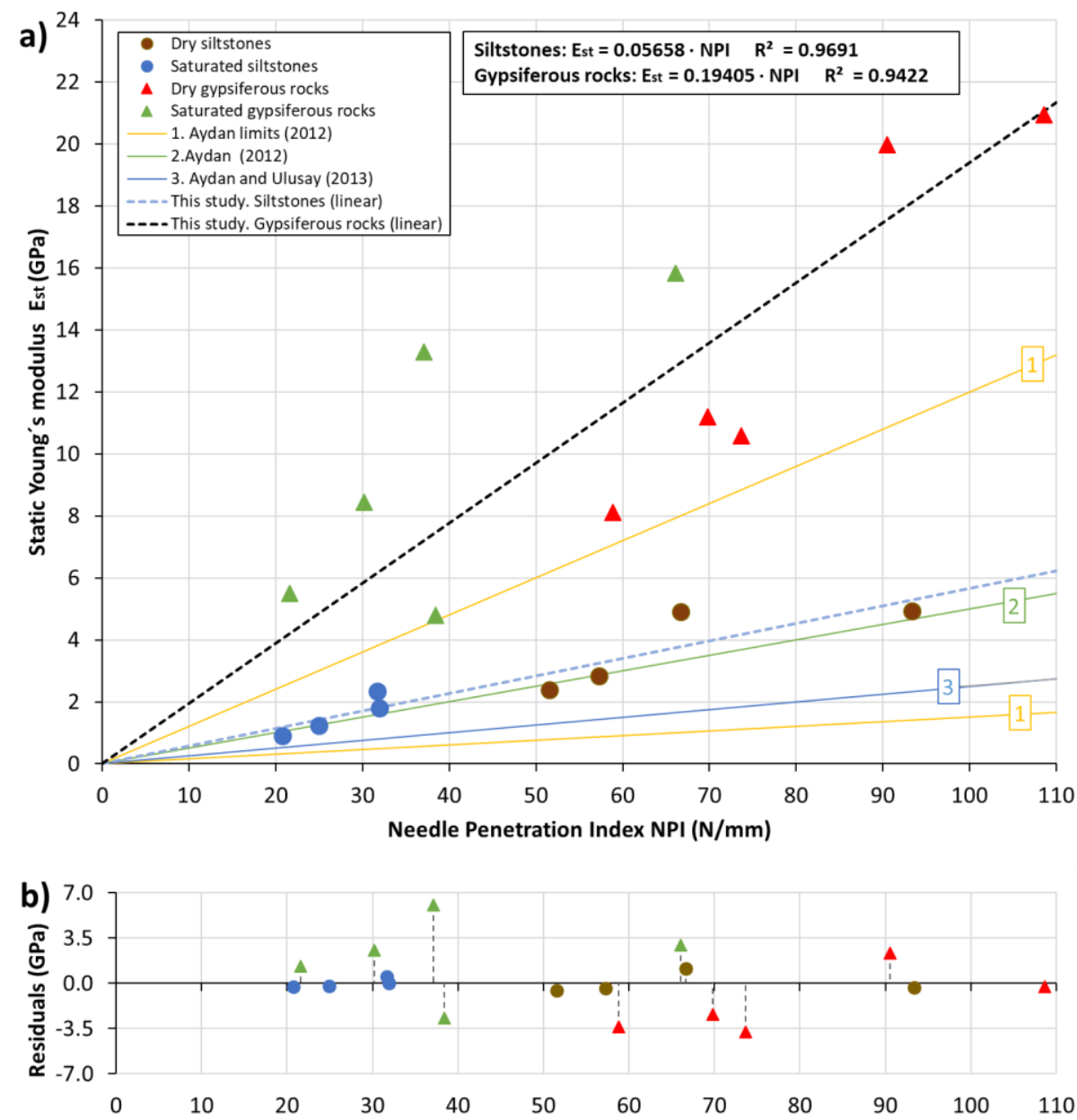

Figure 8. (a) Needle penetration index (NPI) and static Young's modulus ( $\left.E_{s t}\right)$ correlations for dry and saturated siltstone and gypsiferous rock compared to functions reported in published studies. (b) Plotted residuals. 


\section{7. $I_{s(50)}$ and UCS correlations}

While several authors have proposed linear correlations between $I_{s(50)}$ and UCS for several different rock types, very few studies have focused on soft rocks such siltstones and gypsiferous rocks. Results for our regression analyses pointed to significant linear and power correlation functions for the $\mathrm{I}_{\mathrm{s}(50)}$ and UCS for the studied lithologies. In both rock types, the best coefficients of determination were obtained fitting through-the-origin linear functions, as follows:

For dry and saturated siltstones:

$$
\mathrm{UCS}=14.2573 \cdot \mathrm{I}_{\mathrm{S}(50)}\left(\mathrm{R}^{2}=0.9825\right)(\mathrm{Eq} .19 . \mathrm{a})
$$

For dry and saturated gypsiferous rocks:

$$
\mathrm{UCS}=13.6440 \cdot \mathrm{I}_{\mathrm{s}(50)}\left(\mathrm{R}^{2}=0.9433\right)(\mathrm{Eq} \cdot 19 . \mathrm{b})
$$

where UCS and $\mathrm{I}_{\mathrm{s}(50)}$ are both expressed in $\mathrm{MPa}$.

Similar values for factor $k$, which correlates $I_{s(50)}$ and UCS, were reported by Palchik and Hazor (2004) for porous chalks ( $k=8-18$ ) and by Singh et $a l$. (2012) for several rock types ( $k=14-16$ for softer rocks and $k=21$ 24 for harder rocks) (Fig. 9). Significant power correlation functions could also be inferred from the data, as reported by Tsiambaos and Sabatakakis (2004), Kahraman (2014), Diamantis et al. (2009) and Tziallas et al. (2009) for Greek and Turkish rocks, although the coefficients of determination would be lower. The discrepances between linear regression models and test data on UCS and $\mathrm{I}_{s(50)}$ observed in the residual plot could be attributed to the slight differences between some rock blocks and others, as well as, to the different failure mode of specimens in the UCS test. In this line, although the vast majority of specimens fail by axial splitting, very few of them fail by shear macrofracture.
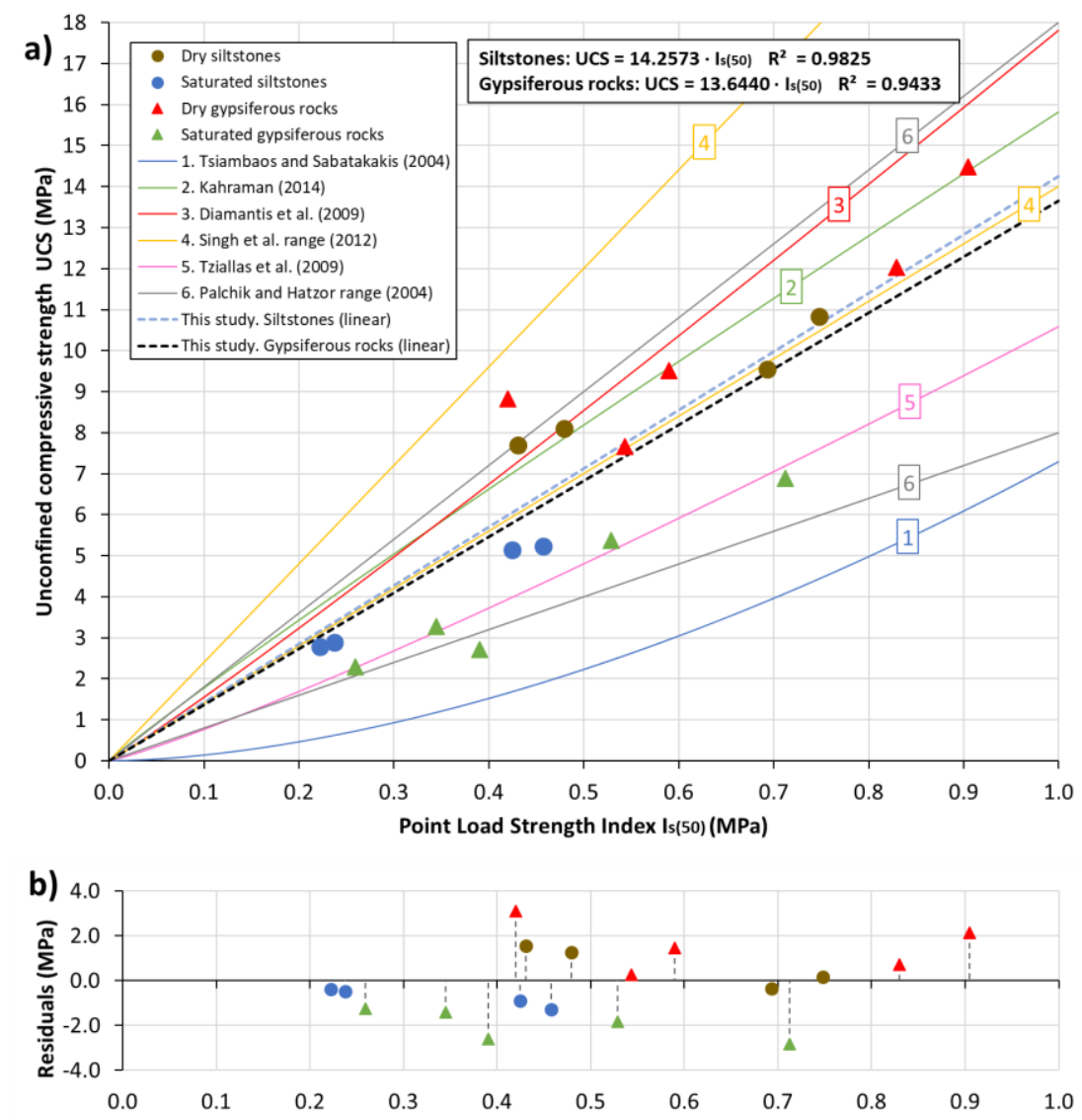

Figure 9. (a) Point load strength index $\left(I_{s(50)}\right)$ and unconfined compressive strength (UCS) correlations for dry and saturated siltstone and gypsiferous rock compared to functions reported in published studies. (b) Plotted residuals. 


\section{8. $I_{s(50)}$ and $E_{s t}$ correlations}

Results for our regression analyses pointed to significant power and linear correlations between $I_{s(50)}$ and $E_{s t}$ for both lithologies, with the best coefficients of determination obtained with through-the-origin linear functions, as follows:

For dry and saturated siltstones:

$$
E_{s t}=6.05674 \cdot I_{S(50)}\left(R^{2}=0.9763\right)(E q .20 . a)
$$

For dry and saturated gypsiferous rocks:

$$
E_{s t}=21.89103 \cdot I_{s(50)}\left(R^{2}=0.9775\right)(E q .20 . b)
$$

where $\mathrm{E}_{\mathrm{st}}$ and $\mathrm{I}_{(50)}$ are expressed in GPa and MPa, respectively.

Similar findings were reported by Daoud et $a l$. (2017) and can be inferred from Kurtulus et $a$. (2012) (Fig. 10). Our results confirm that both the NPT and PLT can be used to indirectly estimate UCS and $E_{s t}$ for dry and saturated siltstone and gypsiferous rock. However, note that, since it is a destructive test, the PLT cannot be used for protected buildings or to monitor rock structures.
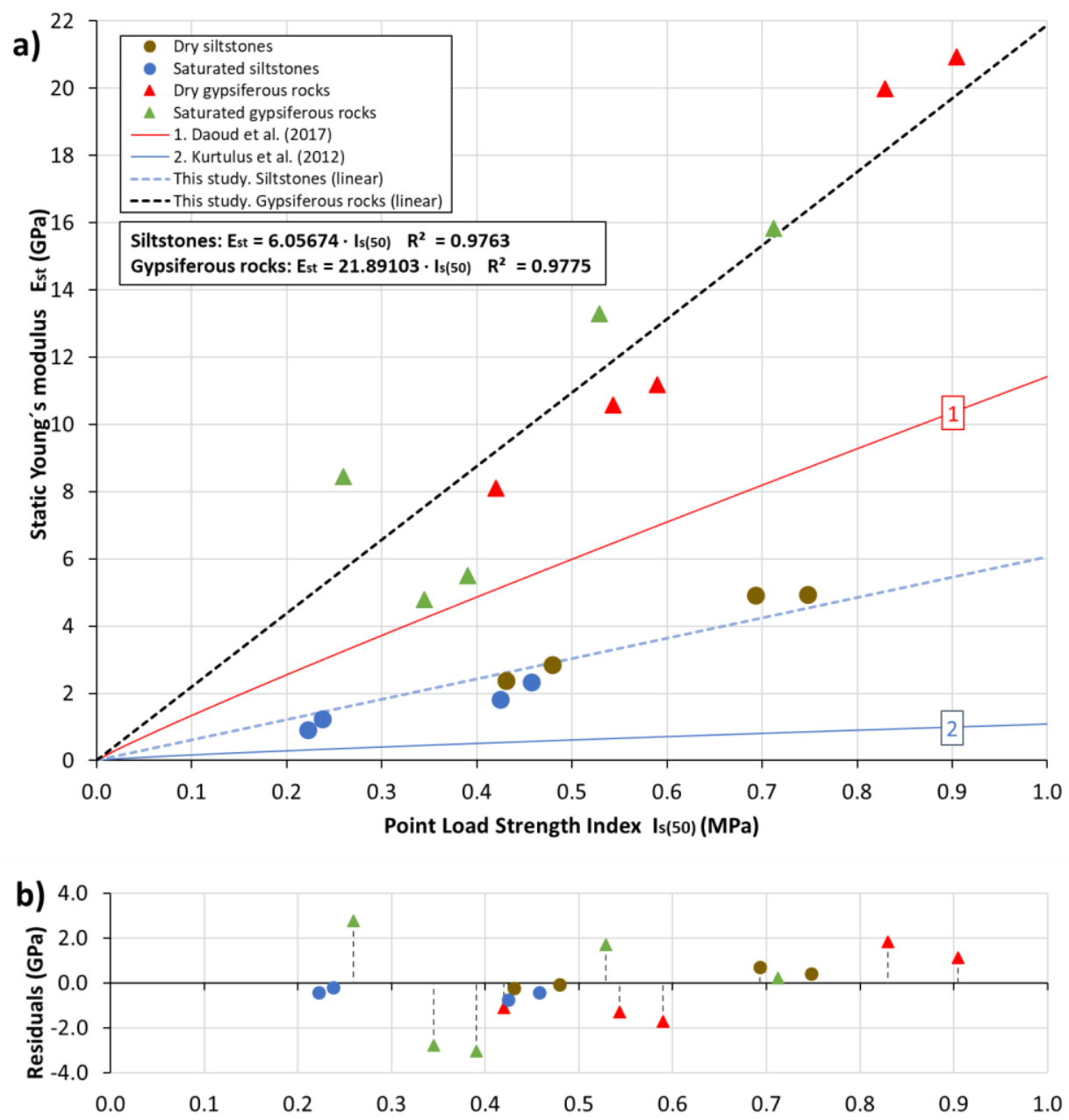

Figure 10. (a) Point load strength index $\left(\mathrm{I}_{s(50)}\right)$ and static Young's modulus $\left(\mathrm{E}_{\mathrm{st}}\right)$ correlations for dry and saturated siltstone and gypsiferous rock compared to functions reported in published studies. (b) Plotted residuals. 


\section{9. $\mathrm{NPI}$ and $\mathrm{I}_{s(50)}$ correlations}

Although both the NPT and $\mathrm{I}_{\mathrm{s}(50)}$ have been used for indirect estimation of UCS, no correlations between them have been published in the literature. In our regression analysis we found that significant linear and power correlation functions could be established between these parameters for siltstone and gypsiferous rock (as might be expected given the results reported above). The best fits were obtained with power-law type regressions (Fig. 11), as follows:

For dry and saturated siltstones:

$$
I_{S(50)}=0.0248 \cdot \mathrm{NPI}^{0.7611} \quad\left(R^{2}=0.8303\right)(E q .21 . a)
$$

For dry and saturated gypsiferous rocks:

$$
I_{s(50)}=0.0417 \cdot \mathrm{NPI}^{0.6328} \quad\left(R^{2}=0.6764\right)(E q .21 . b)
$$

where $\mathrm{NPI}$ and $\mathrm{I}_{\mathrm{s}(50)}$ are expressed in $\mathrm{N} / \mathrm{mm}$ and $\mathrm{MPa}$, respectively.
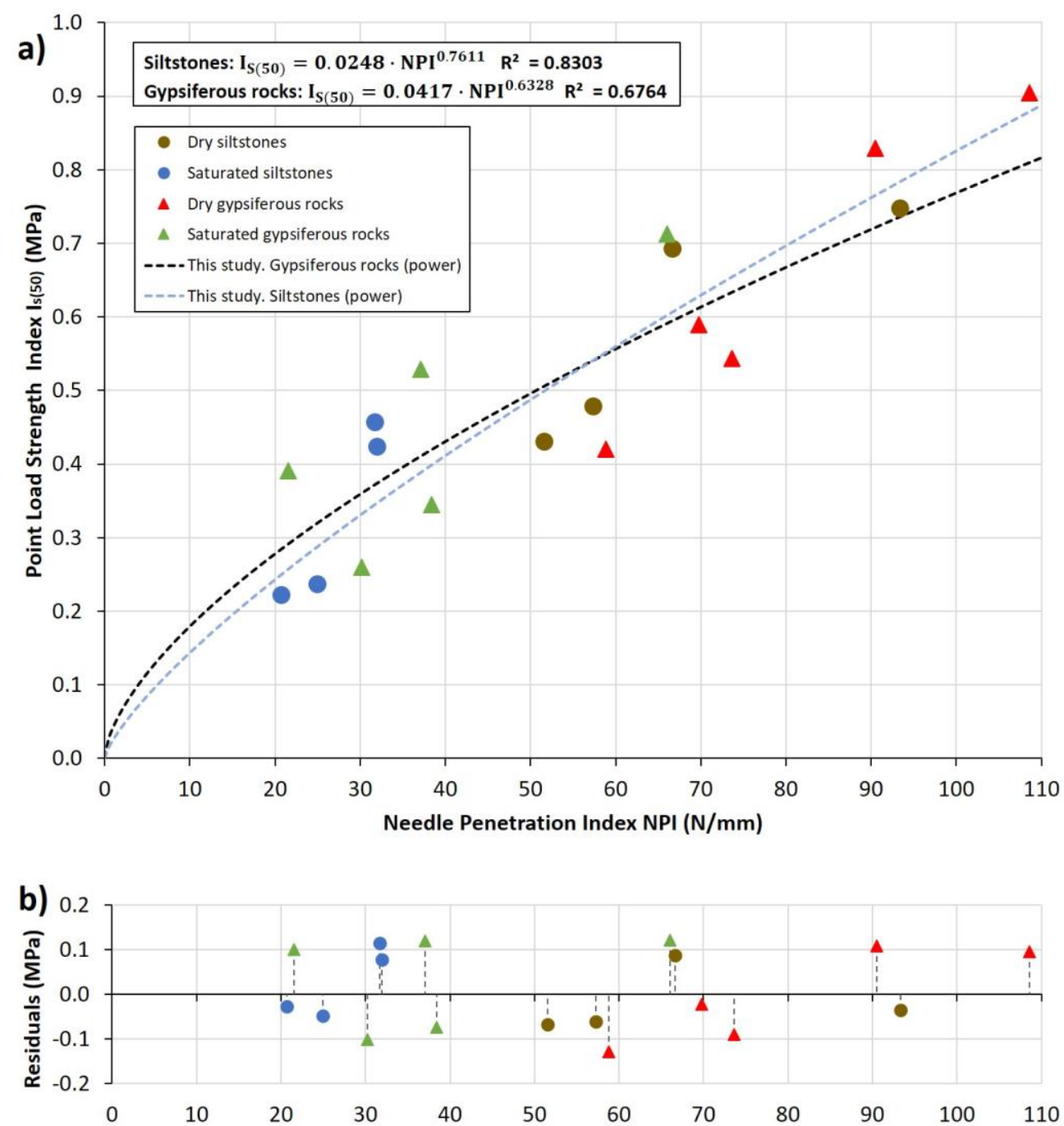

Figure 11. (a) Point load strength index $\left(\mathrm{I}_{5(50)}\right)$ and needle penetration index (NPI) correlations for dry and saturated siltstone and gypsiferous rock. (b) Plotted residuals. 


\section{DISCUSSION}

This paper explores the potential of the NPT and the PLT for indirectly estimating UCS and $\mathrm{E}_{\text {st }}$ for siltstones and gypsiferous soft rocks widely present in southeastern Spain in dry and saturated states. The siltstone is a low-density and very porous rock, with small UCS and $E_{s t}$ values. The gypsiferous rock has smaller porosity and higher density, similar UCS value and a higher $\mathrm{E}_{\text {st }}$ value. Furthermore, both rock types exhibited a marked water weakening effect. Specifically, we obtained a UCS reduction of $56.4 \pm 8.1 \%$ in the siltstone and of $62.0 \pm 10.3 \%$ in the gypsiferous rock and an $E_{s t}$ reduction of $58.0 \pm 7.9 \%$ in the siltstone and of $33.9 \pm 11.9 \%$ in the gypsiferous rock. These results are similar to those previously reported by Erguler and Ulusay (2009) and Yilmaz (2010).

One important finding of this study is that it is possible to estimate mechanical property changes induced by water saturation from reductions in the NPI and $I_{(550)}$ values, which means that relatively more cost-effective and rapid tests like the PLT and NPT can be used. However, the NPT was more sensitive than the PLT in evaluating the saturation effects on rock strength in both types of rock; NPI reductions were $58.4 \pm 6.4 \%$ for the siltstone and $51.1 \pm 17.0 \%$ for the gypsiferous rock, while the $I_{s(50)}$ reductions were more moderate, at $43.9 \pm 7.0 \%$ for the siltstone and $31.9 \pm 14.3 \%$ for the gypsiferous rock. This greater water sensitivity of the NPT means that it can be used in rocks where water effects are less intense, i.e., in a variety of soft or very soft rocks. However, the PLT has the advantage that it can be used in a wider range of rocks overall where use of the NPT would not be possible due to negligible needle penetration in harder rock types.

The UCS, $E_{s t}, N P I$ and $I_{s(50)}$ reductions can be attributed to different and possibly simultaneously occurring physical, chemical and mineralogical causes. One cause could be the decreased surface energy of crack edges when a pore is full of water (Ballivy and Colin, 1999); i.e., the moisture diminishes the spread of free surface energy, thereby facilitating micro-crack propagation by reducing UCS and $E_{s t}$ values (Vasarhelyi and Ledniczky, 1999). Another cause could be the weakening of cementation between grains through dissolution or dispersion (chemical and corrosive deterioration); the presence of water could induce structural changes such as reduced cement quality, lost grain-to-grain contact area, dissolution of calcite or other minerals in the rock matrix or weakened intergranular bonds. All these effects increase the porosity of a rock and consequently reduces its strength. Yet another cause, which could lead to a weakening of mechanical properties, is the swelling of clay minerals, which is very pertinent to clay-bearing sandstones or argillaceous rocks (Erguler and Ulusay, 2009; Tiennot et al., 2019). In this sense, it is important to note that siltstones have small amounts of phyllosilicates and that gypsiferous rocks also contain only very small quantities of clay. The water-weakening mechanism takes place in three stages: the water first penetrates the rock through micro-sized discontinuities, then induces volumetric swelling of clay minerals and the dissolution of carbonate, and, finally, those two effects propagate and connect up cracks (Wong et al., 2016). Finally, an additional factor explaining the weakening of mechanical properties in gypsiferous rocks could be the expansive transformation of bassanite into gypsum due to hydration during the saturation process (Van Driessche et al., 2012).

Another important result of this study is the proposal of significant linear correlation functions not only between the NPI and the UCS, but also between the NPI and the $E_{s t}$ for both types of 
rocks and valid for both dry and saturated conditions. These correlations are especially good (i.e., they present a high $\mathrm{R}^{2}$ ) and significant (i.e., P-value<0.05) for siltstone compared to gypsiferous rock, due to the greater homogeneity of the former, and allow indirect evaluation of the uniaxial strength and deformability of soft rocks using the NPT - a relatively inexpensive and rapid test that does not require any special preparation of the specimens. Furthermore, the NPT can be considered a non-destructive test as it causes practically negligible damage to the rock surface. For this reason, it could feasibly be used to evaluate the mechanical properties of protected natural rock structures and historical or heritage stone buildings. As for the PLT, given the existence of significant correlations between the $I_{s(50)}$ and UCS and between the $I_{s(50)}$ and $E_{s t}$, it could be used as a complementary method to the NPT and could be especially useful to estimate the strength and deformability of somewhat harder rocks for which the NPT is not feasible.

Additionally, the significant correlations between the NPI and the $I_{s}(50)$ suggest the use of the NPT to estimate the strength of soft rocks against concentrated or point loads in a nondestructive manner, something which would not be possible with the PLT. Furthermore, given that the Schmidt hammer test is not suitable for soft rocks (Aydin, 2009) and is less sensitive to mechanical property changes, the NPT may be the only viable non-destructive way to estimate UCS, $I_{s(50)}$ and $E_{s t}$ values, as particularly important input data for a large number of rock engineering applications, including rock mass characterization using classification systems such as RMR. Another advantage of the NPT is that test performance and results retrieval are faster than for the PLT, an important issue, for instance, for tunnels where decisions on supports need to be almost immediate.

A comparative analysis of the different tests available to obtain the mechanical properties of soft rocks, as based on our experience and the results of this study, is provided in Table 6. The most important advantages of NPT are: a) it is particularly suited for the characterization of soft rocks (with UCS lower than $20 \mathrm{MPa}$ ) and is highly sensitive to UCS changes; b) it does not require either special specimen preparations or heavy expensive equipment; c) it can be used in both the field and in the laboratory; d) it requires little to no time for testing and results calculation, which is very useful for determining strength properties in particular circumstances (e.g., for tunnels); and e) because it is non-destructive, rock mechanical strength can be estimated without destroying or rendering protected natural structures or historical or heritage buildings. 
Table 6. Comparative characteristics of tests used to determine unconfined compressive strength (UCS) in rock. FLD: Field; LAB: Laboratory. $\left({ }^{*}\right)$ Some difficulties in preparing soft rocks specimens. $\left({ }^{* *}\right)$ Difficulties of application to soft rocks due to the required high energy. $(* * *)$ Including time required for specimen preparation. $(* * * *)$ This time can be "long" when testing using regular (cylindrical) specimens.

\begin{tabular}{|c|c|c|c|c|}
\hline Test & UCS & $\begin{array}{c}\text { Schmidt } \\
\text { hammer test }\end{array}$ & $\begin{array}{l}\text { Point load } \\
\text { test }\end{array}$ & $\begin{array}{c}\text { Needle } \\
\text { penetration } \\
\text { test }\end{array}$ \\
\hline $\begin{array}{c}\text { Range of application for UCS } \\
\text { determination (MPa) }\end{array}$ & Unlimited & $10-400$ & $1-250$ & $<20$ \\
\hline Determination of UCS & Direct & Indirect & Indirect & Indirect \\
\hline Determination of $\mathrm{E}_{\mathrm{st}}$ & Direct & Not suitable & Indirect & Indirect \\
\hline Application & LAB & FLD/LAB & FLD/LAB & FLD/LAB \\
\hline $\begin{array}{c}\text { Specimen preparation } \\
\text { requirements }\end{array}$ & Yes $(*)$ & No & No & No \\
\hline Destructive test type & Yes & No & Yes & No \\
\hline Suitable for soft rock & Yes & No $(* *)$ & Yes & Yes \\
\hline Relative cost & High & Low & Low & Low \\
\hline Sensitivity & Medium & Very low & Low & High \\
\hline Test duration $(* * *)$ & Long & $\begin{array}{l}\text { Very short } \\
(* * * *)\end{array}$ & Short $(* * * *)$ & $\begin{array}{l}\text { Very short } \\
(* * * *)\end{array}$ \\
\hline Time to results calculation & Short & Very short & Long & Short \\
\hline
\end{tabular}

\section{CONCLUSIONS}

In terms of the potential of the NPT and PLT for indirectly estimating UCS and $\mathrm{E}_{\text {st }}$ for siltstone and gypsiferous rock in dry and saturated states, our main conclusions are as follows:

1) The NPT is a non-destructive, inexpensive, simple and rapid method that can be used in dry and saturated soft rocks to indirectly estimate strength and deformability, in accordance with our proposed linear correlations between the NPI and UCS and between the NPI and $\mathrm{E}_{\text {st }}$ for both lithologies.

2) The NPI is a suitable index to estimate the influence of water on strength and deformability of soft rocks, given that losses due to water saturation are similar to those for UCS and $E_{s t}$.

3) The NPT can be considered non-destructive, given that the damage to rock specimens caused by needle penetration is negligible. This fact, together with the correlations between the NPI and mechanical properties, means that the NPT is especially suitable for estimating strength and deformability parameters for natural or artificial historical rock structures and heritage and protected ancient monuments as well as for monitoring and restoring stone constructions.

4) The PLT, while it can also be used to indirectly estimate UCS and $E_{s t}$ for both lithologies, is a destructive test and is also less sensitive in measuring changes in rock properties caused by water. This limits its potential for use for stone that must be preserved and for less water-sensitive rocks.

5) Finally, the good correlation between NPI and $I_{s(50)}$ indicates the possibility of using the NPT to estimate the strength of soft rocks against concentrated or point loads in a nondestructive and rapid way. 


\section{References}

AENOR (1990a) 'UNE 22-950-90-1. Propiedades mecánicas de las rocas. Ensayos para la determinación de la resistencia. Parte 1: Resistencia a la compresión uniaxial.', Asociación Española de Normalización y Certificación, Madrid., pp. 1-4.

AENOR (1990b) 'UNE 22-950-90-3. Propiedades mecánicas de las rocas. Ensayos para la determinación de la resistencia. Parte 3: Determinación del módulo de elasticidad (Young) y del coeficiente de Poisson.', Asociación Española de Normalización y Certificación, Madrid.

AENOR (1993) 'UNE 103-200-93. Determinación del contenido de carbonatos en los suelos', Asociación Española de Normalización y Certificación, Madrid.

AENOR (1994) 'UNE 103-302-94. Determinación de la densidad relativa de las partículas de un suelo.', Asociación Española de Normalización y Certificación, Madrid., p. 4. Available at: https://es.scribd.com/document/269476259/UNE-103-302-94.

AENOR (2007) 'UNE-EN 1936. Métodos de ensayo para piedra natural. Determinación de la densidad real y aparente y de la porosidad abierta y total.', Asociación Española de Normalización y Certificación, Madrid.

AENOR (2008) ‘UNE-EN 13755. Métodos de ensayo para piedra natural. Determinación de la absorción de agua a presión atmosférica', Asociación Española de Normalización y Certificación, Madrid., pp. 1-10.

Agustawijaya, D. S. (2007) 'The uniaxial compressive strength of soft rock', Civil Engineering Dimension, 9(1), pp. 9-14. Available at: http://puslit.petra.ac.id/journals/civil.

Al-Jassar, S. H. and Hawkins, A. B. (1979) 'Geotechnical properties of the carboniferous limestone of the Bristol area. The influence of petrography and chemistry', in International Society for Rock Mechanics and Rock Engineering (ed.) 4th ISRM Congress. Montreux, Switzerland, pp. 2-8.

Aydan, Ö. (2012) 'The inference of physico-mechanical properties of soft rocks and the evaluation of the effect of water content and weathering on their mechanical properties from needle penetration tests', 46th US Rock Mechanics / Geomechanics Symposium 2012, 1, pp. 410-415.

Aydan, Ö. and Ulusay, R. (2013) 'Geomechanical evaluation of derinkuyu antique underground city and its implications in geoengineering', Rock Mechanics and Rock Engineering, 46(4), pp. 731-754. doi: 10.1007/s00603-012-0301-7.

Aydin, A. (2009) 'ISRM Suggested method for determination of the Schmidt hammer rebound hardness: Revised version', International Journal of Rock Mechanics and Mining Sciences, 46(3), pp. 627-634. doi: 10.1016/j.jirmms.2008.01.020.

Ballivy, G. and Colin, J. C. (1999) 'Stockage souterrain: Influence de la nature du fluide sur les propriétés mécaniques de la roche en paroi', in 9th Int. Cong. on Rock Mech., pp. 563-567.

Bieniawski, Z. (1975) 'The Point Load Test in Geotechnical Practice', Engineering Geology, 9(1), pp. 1-11.

Broch, E. and Franklin, J. A. (1972) 'The point-load strength test', International Journal of Rock 
Mechanics and Mining Sciences and, 9(6), pp. 669-676. doi: 10.1016/0148-9062(72)90030-7.

Carter, P. and Sneddon, M. (1977) 'Comparison of Schmidt Hammer, Point Load and Unconfined Compression Tests in Carboniferous Strata.', in Castle, U. of N. (ed.) Proceeding of a Conference on Rock Engineering. Tyne, England, pp. 197-210.

Daoud, H. S. D., Rashed, K. A. R. and Alshkane, Y. M. A. (2017) 'Correlations of Uniaxial Compressive Strength and Modulus of Elasticity with Point Load Strength Index, Pulse Velocity and Dry Density of Limestone and Sandstone Rocks in Sulaimani Governorate, Kurdistan Region, Iraq', Journal of Zankoy Sulaimani - Part A- (Pure and Applied Sciences), 19(3\&4), pp. 57-72. doi: 10.17656/jzs.10632.

Das, B. . (1985) 'Evaluation of the Point Load Strength for Soft Rock Classification', in Proceeding of the 4th International Conference on Ground Control in Mining. Morgantown, WV, pp. 220-226.

Diamantis, K., Gartzos, E. and Migiros, G. (2009) 'Study on uniaxial compressive strength, point load strength index, dynamic and physical properties of serpentinites from Central Greece: Test results and empirical relations', Engineering Geology. Elsevier B.V., 108(3-4), pp. 199-207. doi: 10.1016/j.enggeo.2009.07.002.

Van Driessche, A. E. S. et al. (2012) 'The role and implications of bassanite as a stable precursor phase to gypsum precipitation', Science, 336, pp. 69-72. doi: 10.1126/science.1215648.

E1621-13, A. (2013) 'Standard Guide for Elemental Analysis by Wavelength Dispersive X-Ray Fluorescence Spectrometry', in ASTM International. West Conshohocken.

Erguler, Z. A. and Ulusay, R. (2009) 'Water-induced variations in mechanical properties of claybearing rocks', International Journal of Rock Mechanics and Mining Sciences, 46(2), pp. 355370. doi: 10.1016/j.jirmms.2008.07.002.

Franklin, J. A. (1985) 'Suggested method for determining point load strength', International Journal of Rock Mechanics and Mining Sciences and, pp. 51-60. doi: 10.1016/01489062(85)92327-7.

Hawkins, A. B. (1998) 'Aspects of rock strength', Bulletin of Engineering Geology and the Environment, 57(1), pp. 17-30. doi: 10.1007/s100640050017.

Ichise, Y., Yamakado, A. and Takano, S. (1974) 'High pressure Jet-Grouting method'.

ISRM (1977) 'Suggested Methods for Determining the Uniaxial Compressive Strength and Deformability of Rock Materials', International Society for Rock Mechanics, pp. 0-3.

Jermy, C. and Bell, F. (1991) 'Coal bearing strata and the stability of coal mines in South Africa', in Engineering, I. S. for R. M. and R. (ed.) 7th ISRM Congress. Aachen, Germany, pp. 11251131.

Kahraman, S. (2014) 'The determination of uniaxial compressive strength from point load strength for pyroclastic rocks', Engineering Geology. Elsevier B.V., 170, pp. 33-42. doi: 10.1016/j.enggeo.2013.12.009.

Kahraman, S. et al. (2017) 'The needle penetration test for predicting coal strength', Journal of the Southern African Institute of Mining and Metallurgy, 117(6), pp. 587-591. doi: 
Kahraman, S., Fener, M. and Kozman, E. (2012) 'Predicting the compressive and tensile strength of rocks from indentation hardness index', Journal of the Southern African Institute of Mining and Metallurgy, 112(5), pp. 331-339.

Kahraman, S. and Gunaydin, O. (2008) 'Indentation hardness test to estimate the sawability of carbonate rocks', Bulletin of Engineering Geology and the Environment, 67(4), pp. 507-511. doi: 10.1007/s10064-008-0162-1.

Kohno, M. and Maeda, H. (2012) 'Relationship between point load strength and uniaxial compressive strength of hydrothermally altered soft rocks', International Journal of Rock Mechanics and Mining Sciences. Elsevier, 50, pp. 147-157. doi: 10.1201/b11646-121.

Kurtulus, C., Bozkurt, A. and Endes, H. (2012) 'Physical and mechanical properties of Serpentinized ultrabasic rocks in NW Turkey', Pure and Applied Geophysics, 169(7), pp. 12051215. doi: 10.1007/s00024-011-0394-z.

Li, D. and Wong, L. N. Y. (2013) 'Point load test on meta-sedimentary rocks and correlation to UCS and BTS', Rock Mechanics and Rock Engineering, 46(4), pp. 889-896. doi: 10.1007/s00603012-0299-x.

Li, Z. et al. (2016) 'Applicability of needle penetration test on soft rocks', Electronic Journal of Geotechnical Engineering, 21(23), pp. 7209-7222.

Maruto Co. Ltd. (2006) Penetrometer for Soft Rock: Model SH-70 Instruction Manual. Tokio (Japan).

Naoto, U., Yoshitake, E., Hidehiro, O., Norihiko, M. (2004) 'Strength evaluation of deep mixing soil-cement by needle penetration test.', Journal of the Japanese Society of Soil Mechanics and Foundation Engineering, 52(7), pp. 23-25.

Okada, S., Izumiya, Y., lizuka, Y., Horiuchi, S. (1985) 'The estimation of soft rock strength around a tunnel by needle penetration test', Journal of the Japanese Society of Soil Mechanics and Foundation Engineering, 33(2), pp. 35-38.

Palchik, V. and Hatzor, Y. H. (2004) 'The Influence of Porosity on Tensile and Compressive Strength of Porous Chalks', Rock Mechanics and Rock Engineering, 37(4), pp. 331-341. doi: 10.1007/s00603-003-0020-1.

Read, J. R. L., Thornten, P. N. and W.M. Regan (1980) 'A rational approach to the point load test', in 3rd Australian-New Zealand Geomechanics Conference. Wellington, pp. 35-39.

Rusnak, J. and Mark., C. (2000) 'Using the point load test to determine the uniaxial compressive strength of coal measure rock', in Peng, S. S. and Mark, C. (eds) Proceedings of the 19th International Conference on Ground Control in Mining. Morgantown, West Virginia, pp. 362-371.

Sabatakakis, N. et al. (2008) 'Index properties and strength variation controlled by microstructure for sedimentary rocks', Engineering Geology, 97(1-2), pp. 80-90. doi: 10.1016/j.enggeo.2007.12.004.

Sadeghiamirshahidi, M. and Vitton, S. J. (2019) ‘Mechanical properties of Michigan Basin’s 
gypsum before and after saturation', Journal of Rock Mechanics and Geotechnical Engineering. Elsevier Ltd, 11(4), pp. 739-748. doi: 10.1016/j.jrmge.2018.10.006.

Singh, T. N., Kainthola, A. and Venkatesh, A. (2012) 'Correlation between point load index and uniaxial compressive strength for different rock types', Rock Mechanics and Rock Engineering, 45(2), pp. 259-264. doi: 10.1007/s00603-011-0192-z.

Smith, H. J. (1997) 'The Point Load Test for weak rock in dredging applications', International Journal of Rock Mechanics and Mining Sciences, 34(295).

Szwedzicki, T. (1998) 'Draft ISRM suggested method for determining the indentation hardness index of rock materials', International Journal of Rock Mechanics and Mining Sciences, pp. 833-835.

Takahashi, K., Noto, K., Yokokawa, I. (1998) 'Strength characteristics of Kobe Formation in Akashi Strata', in 10th Japan National Conf. on Geotech. Eng. The Japanese Geotechnical Society, pp. 1231-1232.

Tiennot, M., Mertz, J. D. and Bourgès, A. (2019) 'Influence of Clay Minerals Nature on the Hydromechanical and Fracture Behaviour of Stones', Rock Mechanics and Rock Engineering. Springer Vienna, 52(6), pp. 1599-1611. doi: 10.1007/s00603-018-1672-1.

Tiryaki, B. and Bolukbasi, N. (2007) 'A Model for Practical Estimation of Rock Cuttability using Cone Indenter Test', in 1st Mining Machinery Symposium of Turkey, pp. 1-7. doi: 10.13140/2.1.3185.0569.

Tsiambaos, G. and Sabatakakis, N. (2004) 'Considerations on strength of intact sedimentary rocks', Engineering Geology, 72(3-4), pp. 261-273. doi: 10.1016/j.enggeo.2003.10.001.

Tziallas, G. P., Tsiambaos, G. and Saroglou, H. (2009) 'Determination of rock strength and deformability of intact rocks', Electronic Journal of Geotechnical Engineering, 14, pp. 1-12.

Uchida, N., Etoh, Y., Ono, H., Miura, N. (2004) 'Strength evaluation of deep mixing soil-cement by needle penetration test. 52(7):23-25', J Jpn Soc Soil Mech Found Eng, 52(7), pp. 23-25.

Ulusay, R. et al. (2014) 'ISRM suggested method for the needle penetration test', Rock Mechanics and Rock Engineering, 47(3), pp. 1073-1085. doi: 10.1007/s00603-013-0534-0.

Ulusay, R. and Erguler, Z. A. (2012) 'Needle penetration test: Evaluation of its performance and possible uses in predicting strength of weak and soft rocks', Engineering Geology. Elsevier B.V., 149-150, pp. 47-56. doi: 10.1016/j.enggeo.2012.08.007.

Vallejo, L., Walsh, R. and Robinson, M. (1989) 'Correlation Between Unconfined Compressive and Point Load Strength for Appalachian Rocks', in Proceeding of the 30th U.S. Symposium on Rock Mechanics, pp. 461-468.

Vasarhelyi, B. and Ledniczky, K. (1999) 'Influence of water-saturation and weathering on mechanical properties of Sivac marble', in 9th Int. Cong. on Rock Mech., pp. 691-693.

Wong, L. N. Y., Maruvanchery, V. and Liu, G. (2016) 'Water effects on rock strength and stiffness degradation', Acta Geotechnica. Springer Berlin Heidelberg, 11(4), pp. 713-737. doi: 10.1007/s11440-015-0407-7. 
Yamaguchi, Y., Ogawa, N., Kawasaki, M., Nakamura, A. (1997) 'Evaluation of seepage failure resistance potential of dam foundation with simplified tests', Journal of the Japan Society of Engineering Geology, 38(3), pp. 130-144.

Yilmaz, I. (2010) 'Influence of water content on the strength and deformability of gypsum', International Journal of Rock Mechanics and Mining Sciences, 47(2), pp. 342-347. doi: 10.1016/j.ijrmms.2009.09.002. 